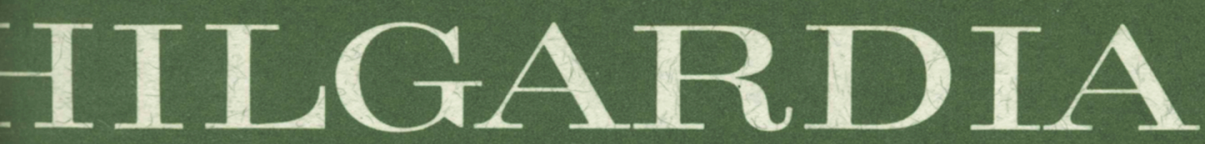

JOURNAL OF AGRICULTURAL SCIENCE PUBLISHED BY ECALIFORNIA AGRICULTURAL EXPERIMENT STATION

Volume 49, Number 2 - February 1981

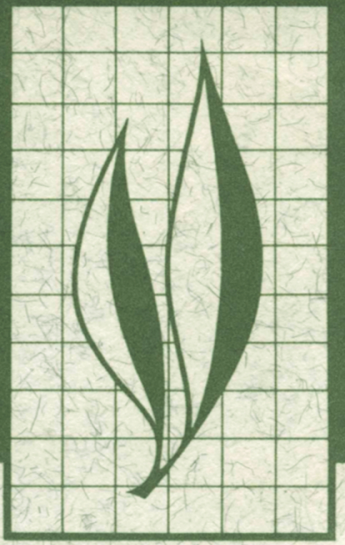

\title{
Germinable Seeds and Periodicity of Germination in Annual Grasslands
}

\author{
J. A. Young, R. A. Evans, \\ C. A. Raguse, and J. R. Larson
}

IIVERSITY OF CALIFORNIA DIVISION OF AGRICULTURAL SCIENCES 


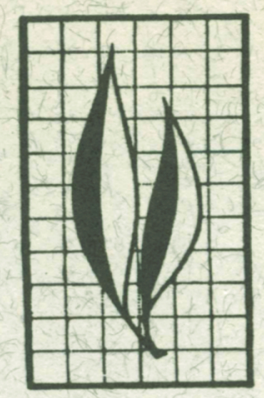

Germinable seed reserves and periodicity of germination of the plant species in annual communities were periodically and intensively sampled from 1974 through 1977 at the Sierra Foothill Range Field Station (SFRFS) and the U.S. Forest Service's San Joaquin Experimental Range (SJER). One hundred samples of surface soil with accompanying litter were taken every 8 weeks, except when they were taken 1, 3, and 5 weeks after annual initial rains.

Few germinable seeds (mostly exotic annual legumes at SFRFS) were carried over from year to year. Dominant annual grasses had virtually no annual carryover. Litterborne and soilborne seed reserves gradually increased as the current year's crop was dispersed. Through the fall, each species exhibited its own pattem of increased germinability, which was highly dependent on its inherent afterripening requirements. In years when the initial fall rains resulted in simultaneous germination, the flush of germination began within a week, and by 5 weeks the reserve of germinable seeds was largely exhausted. The seedlings that established in these years accounted for only 20 to $30 \%$ of the germinable seeds present in the litter and surface soil before the initial rain. When the communities were subjected to 2 years of extreme drought (1975-76 and 1976-77), established seedling density and subsequent seed reserves dropped dramatically; species composition, however, remained relatively stable. Near-normal moisture conditions in 1977-78 resulted in near-normal communities except that a higher percentage of the seed reserve became established plants than before the drought.

\section{THE AUTHORS:}

James A. Young and Raymond A. Evans are range scientists, Science and Education Administration/Agricultural Research, United States Department of Agriculture, Reno, Nevada.

Charles A. Raguse is Professor, Department of Agronomy and Range Science, and Agronomist in the Experiment Station, Davis.

Jeanne R. Larson is range conservationist, Pacific Southwest Forest and Range Experiment Station, Forest Service, United States Department of Agriculture, Fresno, California. 


\section{erminable Seeds and Periodicity of Germination in Annual Grasslands ${ }^{1}$}

\section{INTRODUCTION}

THE GRASSLANDS of California, with a Mediterranean climate, are characterized by a host of alien and native annual plant species (Heady, 1977). Changes in botanical composition caused by the introduction of domestic livestock and annual plants have been rapid and dramatic in these grasslands (Burcham, 1956).

Many types of annual-dominated communities, each of which reflects some combination of parent material, soil, and climate subtype are encompassed in the California grasslands (Evans and Young, 1980). However, all annual species in the various communities share two life-cycle characteristics: 1) seed germination is initiated by the first biologically effective rain in the autumn after the summer drought, and 2) plants escape the aridity and heat of the summer as seeds. Growth of annuals may be restricted by low temperatures if the initial rains occur late in the fall, but germination of all species is nearly simultaneous (Evans, Kay, and Young, 1975). Failure of a species to germinate with the first flush of growth imparts a competitive disadvantage that cannot be compensated for without a reduction of density of the earlier germinating species (Evans, Young, and Kay, 1973).

Species diversity is great in the annual grasslands. Janes (1969) found 129 plant species during the sampling of 20 sites from central to northwestern California. Buttery and Green (1958) list over 350 species at the U.S. Forest Service's San Joaquin Experimental Range in central California. Densities of established plants early in the season may be as high as 200,000 plants $/ \mathrm{m}^{2}$ (per square meter) (Biswell and Graham, 1956). An average population density is 50,000 plants $/ \mathrm{m}^{2}$ (Evans, Kay, and Young, 1975).

Seeds in the litter and soil make an excellent starting point from which to study the population dynamics of these plant communities (Heady, 1977). Reported seed densities in these communities range from 300 to $150,000 / \mathrm{m}^{2}$ (Heady, 1956; Biswell and Graham, 1956; Heady and Torell, 1959; Major, McKell, and Berry, 1960; Sumner and Love, 1961; Major and Pyott, 1966; and Batzli and Pitelka, 1970.) In all of these studies attempts were made to actually count the seeds, and the authors did not determine, or emphasize determination of, the germinability of the seeds recovered.

Bartolome (1976) studied both the germinability of seed reserves and the periodicity of germination in an annual community at the University of California's Hopland Field Station in northwestern California. Seedling densities in these communities reached a maximum within 2 weeks after initial germination. Bartolome also found that numbers of seeds in the soil far exceeded numbers of established seedlings.

Our purposes were to determine the number of germinable seeds in the litter and soil of two representative annual grassland communities and to follow the germinability and periodicity of germination of these seeds through the entire year, and through a series of years, to measure variability of reproduction in these communities.

${ }^{1}$ Accepted for publication April 7, 1980. 


\section{MATERIALS AND METHODS}

\section{Field sites}

Sierra Foothill Range Field Station. Seed reserves were sampled in plant communities at the University of California's Sierra Foothill Range Field Station (SFRFS) in the Sierra Nevada foothills at the eastern edge of the Sacramento Valley near Marysville, California. The experimental site was a blue oak (Quercus douglasii $\mathrm{H}$. and A.)/digger pine (Pinus sabiniana Dougl.) woodland that had been cleared, control-burned, and converted to an annual grassland about 10 years before this experiment.

Soils at the site were members of the fine-loamy, mixed, thermic family of Mollic Haploxeralfs classified in a Las Posas-Sobrante-Auburn-Argonaut series complex. Annual precipitation at the station averages $75 \mathrm{~cm}$ and occurs almost entirely during the fall, winter, and early spring.

Aspect strongly influences plant communities of this foothill area (Evans, Kay, and Young, 1975). We chose contrasting south-facing and north-facing slopes as typical sites for sampling.

San Joaquin Experimental Range. Starting October 1, 1977, we collected bioassay samples from two communities located at the U.S. Forest Service's San Joaquin Experimental Range (SJER) near Coarsegold, California. One site has been maintained as an ungrazed community since 1972 . The other community was grazed by cattle, and, because of the drought during 1976-77, the forage of this site was almost completely utilized, with virtually no plant material left on the soil surface.

Compared with the SFRFS, the SJER represents a drier phase of the annual range type in the Central Valley System. We only sampled for 1 year at this location and used it as a geographical extension of our long-term studies at SFRFS. The study site is an open woodland with a sparse overstory of blue oak, interior live oak (Quercus wislizenii A. DC.), and digger pine. Average annual precipitation is $49 \mathrm{~cm}$. The soils of the San Joaquin Range are derived from decomposing granite or quartz diorite. The soils of the study site are of the Ahwanee series (Chang, 1965) and are classified as members of the coarse-loamy, mixed, thermic family of Mollic Haploxeralfs.

\section{Vegetation sampling}

Each year (1974 to 1978) at the SFRFS we sampled botanical composition and ground cover of the established communities using the step-point method as described by Evans and Love (1957). In 1978, we sampled the plant communities at the SJER using the same method.

\section{Bioassay sampling}

We collected soil and litter samples for seedling counts and bioassay at 8-week intervals, except during the fall germination period. In 1975, 1976, and 1979 we collected samples 1,3 , and 5 weeks after the initial fall rains. Samples were first collected at the SFRFS April 15, 1975, before the year's seed crop had matured and started to disperse, and final samples were collected in June, 1978. The growing season for this typical Mediterranean environment extends from the first effective fall rain, usually mid-October, until 
soil moisture is exhausted, usually mid-May. At the SJER we collected samples from October 1, 1977, to September 15, 1978. The sequence of sampling was the same at each location; only the starting dates were different.

During the spring and summer of 1974, we experimented with various numbers and sizes of samples and sampling depths. Samples consisted of the organic litter, termed mulch for these communities by Hedrick (1948) and Heady (1956), and the mineral soil to depths that varied in 1-cm increments. The structure of the clay-textured soils when they are dry and sun baked makes precise depth control impossible when large numbers of samples are dug. Our preliminary studies showed that most of the germinable seeds were located in the litter, with a few in the surface $1 \mathrm{~cm}$ of soil. So, for the remainder of the study our samples included the litter and the surface $2.5 \mathrm{~cm}$ of soil. Heady (1958) had previously determined that a 2.5 by $2.5 \mathrm{~cm}$ sample was adequate for determinations of seedling densities in these communities. After preliminary trials, we also adopted this size for samples to be tested for germinable seeds. We determined that 100 randomly-located samples from each aspect provided an adequate representation of the germinable seeds of the major species in the communities.

A three-sided frame was used to outline the sample area and a sharpened spatula used to dig the sample. Each sample was placed in a plastic bag and transported to the greenhouse for seedling count and germination tests.

\section{Bioassay of germinable seeds}

Our bioassay technique consisted of a modification of the classical methods of Brenchley (1918) and Brenchley and Warington (1930). After field-established seedlings were identified, counted, and removed, we placed the samples in 12-cm-diameter paper cups on top of a layer of sterile sand and covered the sample with vermiculite. The cups had perforated bottoms. The cups were placed on benches in a greenhouse at 20 to $25^{\circ} \mathrm{C}$ and kept continuously moist. Germinating seedlings were identified as to species, counted, and removed weekly for 8 weeks.

We believe the bioassay method is much more informative than merely counting the recognizable seeds in a sample because (1) a much larger sample size can be used; (2) germination in relation to incubation time can be estimated; (3) samples can be germinated in the microflora and microfauna of the natural environment, which allows the expression of any allelopathic interactions; and (4) seed counts are inaccurate, incomplete, and biased toward large seeds (Bartolome, 1979).

\section{Germination enhancement}

Initial samples collected in April, 1974, at SFRFS were saved after 8 weeks of bioassay, dried, and stored in the laboratory. These samples were stirred, placed in new containers, and retested for germination on October 1, 1974.

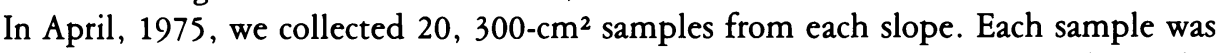
thoroughly mixed and divided into a series of six equal subsamples. These six subsamples were given the following treatments: (1) control, normal bioassay technique; (2) wet weekly with $50 \mathrm{ml}$ of $0.01 \mathrm{mM}$ potassium nitrate $\left(\mathrm{KNO}_{3}\right)$; (3) wet weekly with $50 \mathrm{ml}$ of $0.1 \mathrm{mM} \mathrm{KNO}_{3}$; (4) wet weekly with $50 \mathrm{ml}$ of $1.0 \mathrm{mM} \mathrm{KNO}_{3}$; (5) wet weekly with $50 \mathrm{ml}$ of $0.56 \mathrm{mM}$ gibberellic acid $\left(\mathrm{GA}_{3}\right)$; and (6) wet weekly with $100 \mathrm{ml}$ of a $1: 1$ mixture of $1.0 \mathrm{mM} \mathrm{KNO}_{3}$ and $0.56 \mathrm{mM} \mathrm{GA}_{3}$. These procedures were suggested by previous re- 
search on germination enhancement of Bromus tectorum L. seeds that had exhibited field-acquired dormancy (Evans and Young, 1975).

\section{RESULTS AND DISCUSSION}

\section{Location of seeds}

Even in the spring, when seed reserves were lowest, 85 percent of the germinable seeds were located in the litter on top of the mineral soil (Fig. 1). In October, at the peak of seed reserves, 96 percent of the germinable seeds were located in the litter, and the remainder, in the surface $2 \mathrm{~cm}$ of mineral soil.

Sampling to $2.5 \mathrm{~cm}$ deep in the surface soil reached seeds of Erodium spp., which have a self-burial mechanism (Young, Evans, and Kay, 1975). Major and Pyott (1966) reported that some seeds, especially the minute seeds of Tillaea erecta $\mathrm{H}$. and A., germinated from soil samples taken from depths of 2.5 to $5.0 \mathrm{~cm}$ in California grasslands. Harper (1977) has recently reviewed mechanisms of deep seed burial by natural means, including those factors that undoubtedly function in annual grasslands of California, such as capillary flow of microscopic seeds, earthworm ingestions and excretions, harvester ant activities, and, probably most importantly, rodent caches and disturbances. The important phenomenon in the ecology of the plant communities is not the small number of seeds that are buried deeply but the overwhelming abundance of seeds in the litter on the soil surface.

\section{Variability in seed reserves}

Seed production and seed reserves, like other biological characteristics of annual plant communities, are highly variable among years, reflecting variation in the amount and seasonal timing of precipitation (Murphy, 1970, Duncan and Woodmansee, 1975).

The initial seed reserves we sampled were composed of seeds produced in 1973-74, a relatively wet growing season with rainfall at SFRFS of $103 \mathrm{~cm}$ (Table 1 ), $27 \mathrm{~cm}$ above the long-term average. The growing-season precipitation during $1974-75,68 \mathrm{~cm}$, was

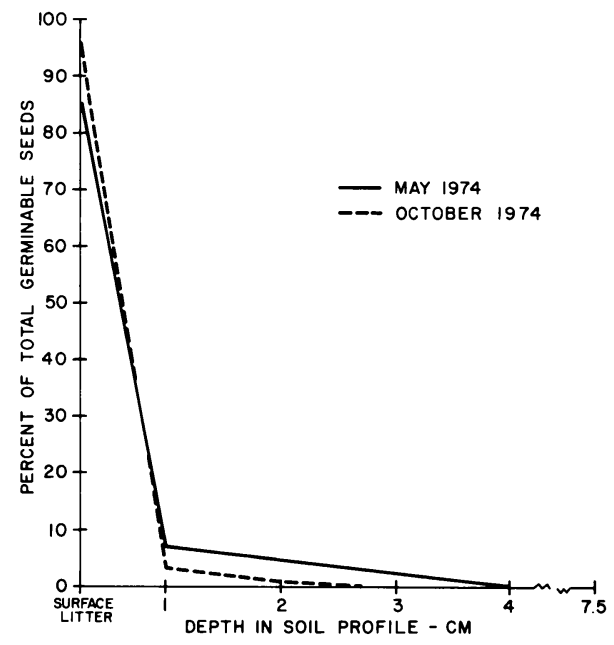

Fig. 1. Location of germinable seeds in the litter and surface soil $(7.5 \mathrm{~cm})$ at the Sierra Foothill Range Field Station in May and October, 1974. Germinability determined by bioassay. 
TABLE 1.

MONTHLY PRECIPITATION FOR THE SIERRA FOOTHILL RANGE FIELD STATION (SFRS) AND THE SAN JOAQUIN EXPERIMENTAL RANGE (SJER)—JUNE 1973 TO MAY 1978

\begin{tabular}{|c|c|c|c|c|c|c|c|c|c|c|c|c|c|}
\hline \multirow{2}{*}{$\begin{array}{r}\text { Growing } \\
\text { season }\end{array}$} & \multicolumn{13}{|c|}{ Monthly precipitation (centimeters) in: } \\
\hline & June & July & Aug. & Sept. & Oct. & Nov. & Dec. & Jan. & Feb. & March & April & May & Total \\
\hline \multicolumn{14}{|c|}{ SFRFS } \\
\hline $1973-74$ & 0 & 0 & 0 & 1.0 & 8.4 & 34.5 & 14.2 & 13.4 & 6.6 & 19.9 & 4.1 & 1.2 & 103.3 \\
\hline $1974-75$ & 0.4 & 5.8 & 0 & 0 & 3.2 & 3.0 & 5.6 & 6.1 & 23.2 & 16.5 & 4.6 & 0 & 68.4 \\
\hline $1975-76$ & 0 & 0.3 & 0.6 & 0.1 & 9.0 & 3.8 & 4.2 & 1.9 & 5.5 & 2.9 & 6.2 & 0 & 34.5 \\
\hline $1976-77$ & 0.1 & 0 & 2.1 & 2.3 & 0.4 & 2.6 & 1.0 & 6.6 & 4.3 & 3.2 & 0.6 & 3.9 & 27.1 \\
\hline $1977-78$ & 0 & 0.1 & 0 & 1.9 & 0.6 & 6.7 & 14.8 & 27.9 & 11.0 & 16.9 & 17.0 & 0.4 & 97.3 \\
\hline \multicolumn{14}{|c|}{ SJER } \\
\hline $1973-74$ & 0.2 & 0 & 0 & 0 & 6.4 & 7.5 & 12.0 & 11.7 & 1.6 & 10.6 & 7.7 & 0 & 57.7 \\
\hline $1974-75$ & 0 & 0.2 & 0 & 0 & 7.0 & 3.8 & 6.9 & 3.5 & 10.6 & 10.8 & 4.6 & 0.2 & 47.6 \\
\hline $1975-76$ & 0 & 0 & 0.1 & 0.5 & 7.2 & 1.4 & 1.0 & 0.4 & 13.6 & 4.2 & 2.8 & 0.1 & 31.3 \\
\hline $1976-77$ & 0.5 & 0 & 0.1 & 3.7 & 2.3 & 3.0 & 2.2 & 2.9 & 1.2 & 2.4 & 0.1 & 3.7 & 22.1 \\
\hline $1977-78$ & 1.6 & 0 & 0 & 0.2 & 0.2 & 3.6 & 14.7 & 16.3 & 16.5 & 16.2 & 12.0 & 0 & 81.3 \\
\hline
\end{tabular}

near normal. These 2 years permitted benchmark measurements of seed reserves in normal and wet growing seasons.

In 1974, rainfall in July, a usually dry period of the year for the annual communities, was $5.8 \mathrm{~cm}$. This unseasonable rain resulted in some germination (Raguse, Young, and Evans, 1977).

The period from June, 1975, through August, 1977, was a near record drought for much of California. This drought severly influenced the vegetation of the annual plant communities. Precipitation at SFRFS totaled $35 \mathrm{~cm}$ in 1975-76 and $27 \mathrm{~cm}$ in 1976-77. These 2 drought years provided a sharp contrast with the previous 2 baseline years for comparison of seed reserves and their germinability. Precipitation returned to abovenormal levels in 1977-78 with $97 \mathrm{~cm}$. We refer to this as the drought-recovery year.

The date and magnitude of the first rain in the fall that initiates germination are very important in the dynamics of annual communities. (Evans, Kay, and Young, 1975). Usually germination-initiating rain occurs in October, as in 1973, 1974, and 1975.

\section{Dynamics of germinable seed populations}

The seed reserves of annual grasslands are extremely dynamic during the year (Figs. 2a and $2 \mathrm{~b}$ ). In wet years, total numbers of germinable seeds ranged from a low of less than $2,000 / \mathrm{m}^{2}$ in April to almost $300,000 / \mathrm{m}^{2}$ in October (Fig. 2a) before the first fall rain that ends the summer drought. The low point in the reproductive reserves was the striking part of this dynamic cycle. In dry years, total reserves dropped to less than 1,000 germinable seeds $/ \mathrm{m}^{2}$ and peaked at $62,000 / \mathrm{m}^{2}$ (Fig. $2 \mathrm{~b}$ ).

Most of the germinable seeds in both wet and dry years were caryopses of annual grasses. Proportionally, grass caryopses contributed a smaller portion of the reserve at low points in the annual cycle.

\section{Carryover of germinable seeds}

Compared to the peak numbers of germinable seeds in October, the number of germinable seeds was very low each year in April before the current year's seeds were ripe (Figs. $2 \mathrm{a}$ and $2 \mathrm{~b}$ ). The overwhelming bulk of the reproductive reserve carried from year 


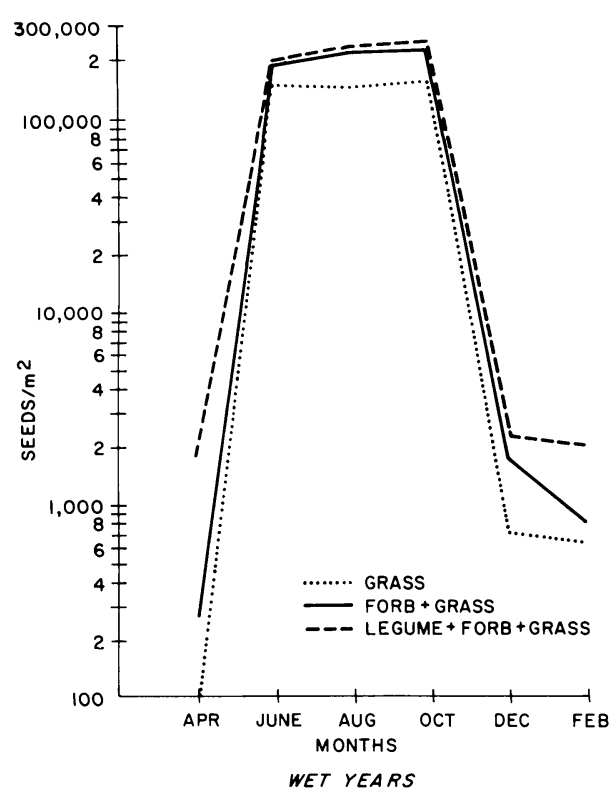

Fig. 2a. Annual cycle of germinable seed populations in the litter and surface soil $(2.5 \mathrm{~cm})$ during wet years in annual grassland communities at Sierra Foothill Range Field Station.

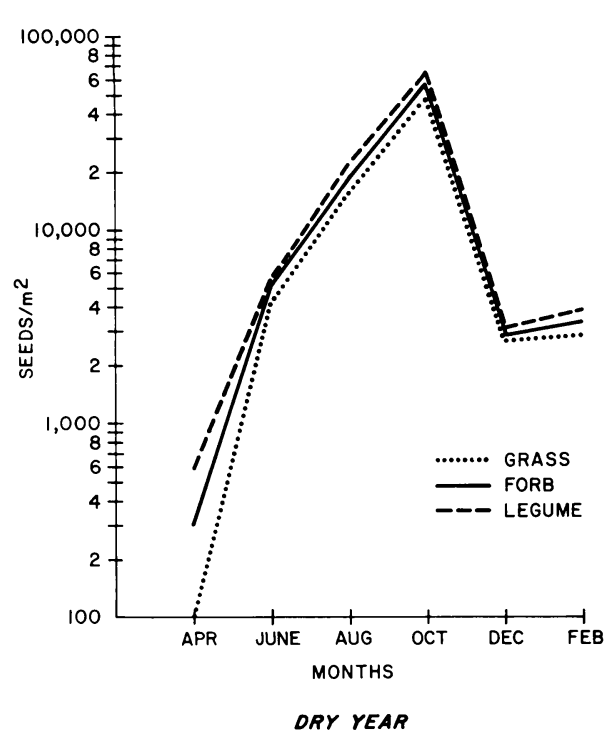

Fig. 2b. Annual cycle in germinable seed populations in the litter and surface soil $(2.5 \mathrm{~cm})$ during dry years in annual grassland communities at Sierra Foothill Range Field Station.

to year consisted of seeds of legumes (82\%), especially the exotics Trifolium hirtum All. and Medicago polymorpha L. (Table 2). Seed lots of T. hirtum produced in the Mediterranean environments of California tend to have a high percentage of hard seed (Williams, Love, and Berry, 1957, Young, Evans, and Kay, 1973). Very few grass caryopses were germinable in these samples. Bromus mollis L. was the most frequent grass species in the samples from the low point in reproductive reserve but accounted for only 4 percent of the total germinable seeds. The carryover in Bromus mollis caryopses was roughly 0.002 percent of germinable caryopses of this species found in October.

Numbers of carryover or residual seeds that were germinable were lower after dry than wet growing seasons, but there were only few accompanying large changes in species composition resulting from this year-to-year variation in precipitation. Species of Trifolium other than $T$. hirtum and Medicago polymorpha had considerably fewer germinable seeds, but the legumes continued to contribute the bulk (64 percent) of the residual seeds (Table 2 ).

At the end of the recovery growing season (1977-78) after the 2 years of drought (1975-76 and 1976-77), residual reserves of germinable seeds returned to levels similar to those observed before the drought (Table 2). Again, legumes dominated the germinable seeds (89 percent), with Trifolium subterraneum L. at a relatively high level.

Delayed germination. Additional germination was obtained from samples that were taken and tested in April and stored until October 1974, when they were rewet and retested. Legumes and other broad-leaved species, rather than the dominant annual grasses, accounted for this germination (Table 3).

Enhancing germination. The only group of species whose germination was enhanced by the addition of $\mathrm{KNO}_{3}$ or $\mathrm{GA}_{3}$ to the samples was the miscellaneous broad-leaved plants (Table 4). Varying the concentration or type of enhancement material may be a 
TABLE 2.

GERMINABLE SEEDS RECOVERED FROM THE LITTER PLUS THE SURFACE $2.5 \mathrm{CM}$ OF SOIL IN APRIL BEFORE CURRENT YEAR'S CROP OF SEEDS WERE MATURE*

\begin{tabular}{|c|c|c|c|}
\hline \multirow[b]{2}{*}{ Species } & \multicolumn{3}{|c|}{ Germinable seeds per $\mathbf{m}^{2}$} \\
\hline & $\begin{array}{c}\text { Wet } \\
\text { seasons } \\
(1973-4)\end{array}$ & $\begin{array}{c}\text { Dry } \\
\text { seasons } \\
(1975-6)\end{array}$ & $\begin{array}{c}\text { Recovery } \\
\text { season } \\
(1977)\end{array}$ \\
\hline Bromus mollis & 22 & 36 & 18 \\
\hline B. diandrus & 2 & 8 & 0 \\
\hline B. madritensis & 10 & 8 & 12 \\
\hline $\begin{array}{l}\text { Avena barbata } \\
\text { Taeniatherum }\end{array}$ & 8 & 12 & 2 \\
\hline asperum & 10 & 20 & 10 \\
\hline Vulpia megalura & 8 & 18 & 16 \\
\hline Aira caryophyllea & 0 & 8 & 0 \\
\hline Trifolium hirtum & 510 & 420 & 612 \\
\hline T. subterraneum & 170 & 60 & 310 \\
\hline $\begin{array}{l}T . \text { spp. } \\
\text { Medicago }\end{array}$ & 310 & 38 & 100 \\
\hline polymorpha & 490 & 62 & 380 \\
\hline Misc. forbs & 210 & 210 & 110 \\
\hline Total & 1750 & 900 & 1570 \\
\hline
\end{tabular}

"Data for north and south slopes at Sierra Foothill Range Field Station are combined.
TABLE 3.

GERMINABLE SEEDS IN BIOASSAY SAMPLES COLLECTED AT THE SIERRA FOOTHILL RANGE FIELD STATION IN APRIL, 1974, TESTED IMMEDIATELY, AND AFTER STORAGE FOR 1 YEAR

\begin{tabular}{lcc}
\hline \hline & \multicolumn{2}{c}{ Germinable seeds per m ${ }^{2 *}$} \\
\cline { 2 - 3 } Species & $\begin{array}{c}\text { Initial test } \\
\text { (April 15, 1974) }\end{array}$ & $\begin{array}{c}\text { Second test } \\
\text { (October 1, 1974) }\end{array}$ \\
\hline Bromus mollis & 19 & 0 \\
B. diandrus & 4 & 0 \\
B. madritensis & 12 & 0 \\
Avena barbata & 6 & 0 \\
Taeniatherum & & \\
$\quad$ asperum & 9 & 0 \\
Vulpia megaluria & 6 & 0 \\
Trifoluim birtum & 480 & 130 \\
T. subterraneum & 190 & 60 \\
T. spp. & 420 & 80 \\
Medicago & & 10 \\
polymorpha & 310 & 80 \\
Misc. forbs & 180 & 360 \\
Total & 1636 & \\
\hline
\end{tabular}

*Mean numbers of germinable seeds for both slopes, except for Bromus diandrus, which occurred on the north slope only, and Taeniatherum asperum, which in 1974 occurred on the south slope only.

TABLE 4

GERMINABLE SEEDS FROM SAMPLES COLLECTED AT THE SIERRA FOOTHILL RANGE FIELD STATION IN APRIL 1975 AND SUBJECTED TO GERMINATION-ENHANCED TREATMENTS. *

\begin{tabular}{|c|c|c|c|c|c|c|}
\hline \multirow[b]{3}{*}{ Species } & \multicolumn{6}{|c|}{ Germinable seeds per $\mathrm{m}^{2}$ with indicated treatment } \\
\hline & \multirow{2}{*}{$\frac{\text { None }}{\text { (Control) }}$} & \multicolumn{3}{|c|}{$\mathrm{KNO}_{3}$} & \multirow{2}{*}{$\frac{\mathrm{GA}_{3}}{0.56 \mathrm{mM}}$} & \multirow{2}{*}{$\frac{\mathrm{GA}_{3}+\mathrm{KNO}_{3}}{0.56 \mathrm{mM}+1.0 \mathrm{mM}}$} \\
\hline & & $0.01 \mathrm{mM}$ & $0.1 \mathrm{mM}$ & $1.0 \mathrm{mM}$ & & \\
\hline Bromus mollis & 22 & 18 & 16 & 24 & 12 & 24 \\
\hline B. diandrus & 2 & 4 & 2 & 6 & 2 & 8 \\
\hline B. madritensis & 16 & 10 & 14 & 12 & 8 & 14 \\
\hline Avena barbata & 8 & 2 & 5 & 4 & 14 & 8 \\
\hline Taeniatherum asperum & 14 & 8 & 12 & 6 & 10 & 4 \\
\hline Vulpia megalura & 10 & 4 & 4 & 8 & 6 & 4 \\
\hline Trifolium hirtum & 420 & 380 & 410 & 470 & 400 & 440 \\
\hline T. subterraneum & 140 & 210 & 240 & 180 & 120 & 130 \\
\hline$T$. spp. & 260 & 310 & 240 & 190 & 180 & 240 \\
\hline Medicago polymorpha & 290 & 300 & 210 & 340 & 300 & 320 \\
\hline Misc. forbs & $160 d$ & $180 \mathrm{~d}$ & $290 c$ & $320 \mathrm{~b}$ & $170 \mathrm{~d}$ & $410 a$ \\
\hline Total & 1,342 & 1,426 & 1,443 & 1,560 & 1,222 & 1,602 \\
\hline
\end{tabular}

-Means for miscellaneous forbs followed by the same letter are not significantly different at the 0.05 level of probability, as determined by Duncan's multiple range test. Means of other species or groups did not differ significantly with treatment.

very fruitful type of research for the annual grassland species; however, we felt the preliminary results did not justify continuing such research in the study. The negative results suggest that seeds of the dominant annual grasses in plant communities at the SFRFS do not acquire an environmentally induced dormancy that responds to $\mathrm{KNO}_{3}$ or $\mathrm{GA}_{3}$, as does Bromus tectorum (Evans and Young, 1975). 


\section{Initial germination in the field}

Seed reserve and germination data characterize responses to four combinations of production- and germination-moisture conditions: (1) seed production in a wet year followed by germination in a wet year (1974); (2) seed production in a wet year followed by germination in a dry year (1975); (3) seed production in a dry year followed by germination in a dry year (1976); and (4) seed production in a dry year followed by germination in a wet year (1977).

Numbers of germinable seeds of the three key species, Bromus mollis, Erodium botrys (Cav.) Bertol., and Trifolium hirtum, before the first effective fall rain were significantly $(p=0.01)$ lower in dry production seasons than in any other (Table 5). The combination of two dry years (1975 and 1976) tended to further reduce numbers of seeds for all three species, but the reduction was statistically significant $(\mathrm{p}=0.01)$ only for $T$. hirtum.

1974: Seed produced and germinated in a wet year. Because we did not realize how rapidly seed reserves were exhausted after the initial rain, we did not adequately sample during the germination period in 1974. The October 1, 1974, sampling indicated that the north slope supported a higher density of germinable seeds than did the south slope (Table 6). Bromus mollis was the most abundant species on both slopes, composing 44 percent of the germinable seeds on the north and 46 percent of those on the south. Bromus diandrus Roth was restricted to the north slope and Hordeum bystrix Roth to the south. Trifolium hirtum was clearly the dominant legume on the north slope, while it shared dominance with $T$. subterraneum on the south slope. Seed reserves of Erodium botrys, Stellaria media (L.) Cyrill., and Geranium spp. were more abundant on the north than on the south slope.

1975: Seed produced in a wet year and germinated in a dry year. The winter of 1975-76 was very dry (Table 1), with precipitation only half of the normal. However, germination in 1975 was initiated by abundant fall precipitation $(9.03 \mathrm{~cm})$. The first rain, $1.2 \mathrm{~cm}$, occurred October 6 and 7 and was followed by $4.6 \mathrm{~cm}$ on October 10 and 11 (Fig. 3a). Germinable seeds on October 1, before the first effective rain, totaled $265,500 / \mathrm{m}^{2}$ on the north slope and $186,300 / \mathrm{m}^{2}$ on the south slope (Fig. 3a, Tables $7 \mathrm{a}$ and $\mathrm{b})$.

Bromus mollis is a key species because of its abundance (39\% of the total Oct. 1 seed reserve). One week after the initial rain, $B$. mollis seedlings became established at $21,400 / \mathrm{m}^{2}$ on the north slope and $19,300 / \mathrm{m}^{2}$ on the south slope (Tables $7 \mathrm{a}$ and $\mathrm{b}$ ). Samples of the litter and surface $2.5 \mathrm{~cm}$ of soil taken at the end of the first week after the initial rain germinated 27,800 and $28,600 \mathrm{~B}$. mollis seedlings $/ \mathrm{m}^{2}$ from north and south

TABLE 5.

GERMINABLE SEEDS OF THREE KEY SPECIES IN THE LITTER AND SOIL AT THE SIERRA FOOTHILL RANGE FIELD STATION BEFORE THE FIRST GERMINATION-EFFECTIVE FALL RAIN 1974 THROUGH 1977

\begin{tabular}{lrccc}
\hline \hline & \multicolumn{4}{c}{ Germinable seeds (x 1000) per $\mathbf{~ m}^{\mathbf{2 *}}$} \\
\cline { 2 - 5 } Species & $\mathbf{1 9 7 4}$ & $\mathbf{1 9 7 5}$ & $\mathbf{1 9 7 6}$ & $\mathbf{1 9 7 7}$ \\
\hline Bromus mollis & $101.4 \mathrm{a}$ & $90.6 \mathrm{a}$ & $16.2 \mathrm{~b}$ & $\mathbf{8 . 1 \mathrm { b }}$ \\
Erodium botrys & $18.4 \mathrm{a}$ & $15.6 \mathrm{a}$ & $1.8 \mathrm{~b}$ & $0.6 \mathrm{~b}$ \\
Trifolium hirtum & $19.6 \mathrm{a}$ & $18.0 \mathrm{a}$ & $5.5 \mathrm{~b}$ & $3.5 \mathrm{c}$ \\
\hline
\end{tabular}

*Within species, means followed by the same letter are not statistically different at the 0.01 level of probability, as determined by Duncan's multiple range test. 
TABLE 6.

GERMINABLE SEED RESERVES AT THE SIERRA

FOOTHILL RANGE FIELD STATION ON

OCTOBER 1, 1974, BEFORE THE FIRST

GERMINATION-EFFECTIVE PRECIPITATION

\begin{tabular}{|c|c|c|}
\hline \multirow[b]{2}{*}{ Species } & \multicolumn{2}{|c|}{ Germinable seeds $(x \mathbf{1 0 0 0})$ per $\mathrm{m}^{2}$} \\
\hline & North slope & South slope \\
\hline \multicolumn{3}{|l|}{ Grasses } \\
\hline Bromus mollis & 119.3 & 83.5 \\
\hline B. diandrus & 3.1 & 0 \\
\hline B. madritensis & 11.2 & 12.1 \\
\hline $\begin{array}{l}\text { Avena barbata } \\
\text { Taeniatherum }\end{array}$ & 4.9 & 1.2 \\
\hline asperum & 3.1 & 1.1 \\
\hline Vulpia megalura & 32.4 & 27.2 \\
\hline Hordeum bystrix & 0 & 3.1 \\
\hline \multicolumn{3}{|l|}{ Legumes } \\
\hline Trifolium birtum & 26.9 & 12.3 \\
\hline T. subterraneum & 5.6 & 14.3 \\
\hline $\begin{array}{l}\text { Trifolium spp. } \\
\text { Medicago }\end{array}$ & 0.9 & 1.9 \\
\hline polymorpha & 0.8 & 6.1 \\
\hline Misc. legumes & 0.1 & 0.3 \\
\hline \multicolumn{3}{|l|}{ Forbs } \\
\hline Erodium botrys & 28.4 & 8.4 \\
\hline E. cicutarium & 4.6 & 0.1 \\
\hline $\begin{array}{l}\text { Stellaria media } \\
\text { Hypochoeris }\end{array}$ & 14.6 & 1.0 \\
\hline glabra & 0.4 & 1.1 \\
\hline Geranium spp. & 11.1 & 1.8 \\
\hline Misc. forbs & 3.1 & 5.4 \\
\hline Total & 270 & 180 \\
\hline
\end{tabular}

slopes, respectively. Germinable seed reserves and the established seedlings of $B$. mollis 1 week after the initial rain accounted for 47 and 62 percent of the germinable seeds recorded 10 days earlier on October 1 on north and south slopes, respectively.

With time after the initial rains, the germinable seed reserves dropped, and the amount of the October 1 reproductive reserve that was accounted for rapidly decreased. At 3 weeks after the initial rain, 23 and 30 percent of the October 1 germinable reserves from the north and south slopes, respectively, were accounted for; at 5 weeks after the initial rain, 21 percent of the reserves from the north slope and 28 percent from the south were all that could be identified. Most of the October 1 germinable seeds that were accounted for at this date were represented by established seedlings (21 percent north and 27 percent south). Germinable seed reserves of Bromus mollis 5 weeks after the initial rain were 0.1 and 0.4 percent of those available on October 1 on the north and south slopes, respectively.

The trend for most species was similar to that for Bromus mollis; 30 and 23 percent of the October reproductive potential were accounted for by seed reserves and established seedlings on the south and north slopes, respectively, 5 weeks after the initial rain (Fig. 3a). However, there were several notable exceptions. Seeds of Taeniatherum asperum (Simonkai.) Nevski have an inherent afterripening requirement that is related to temperature (Young, Evans, and Eckert, Jr., 1968). On October 1, these afterripening requirements were not fully satisfied, and no seedlings were established the first week 


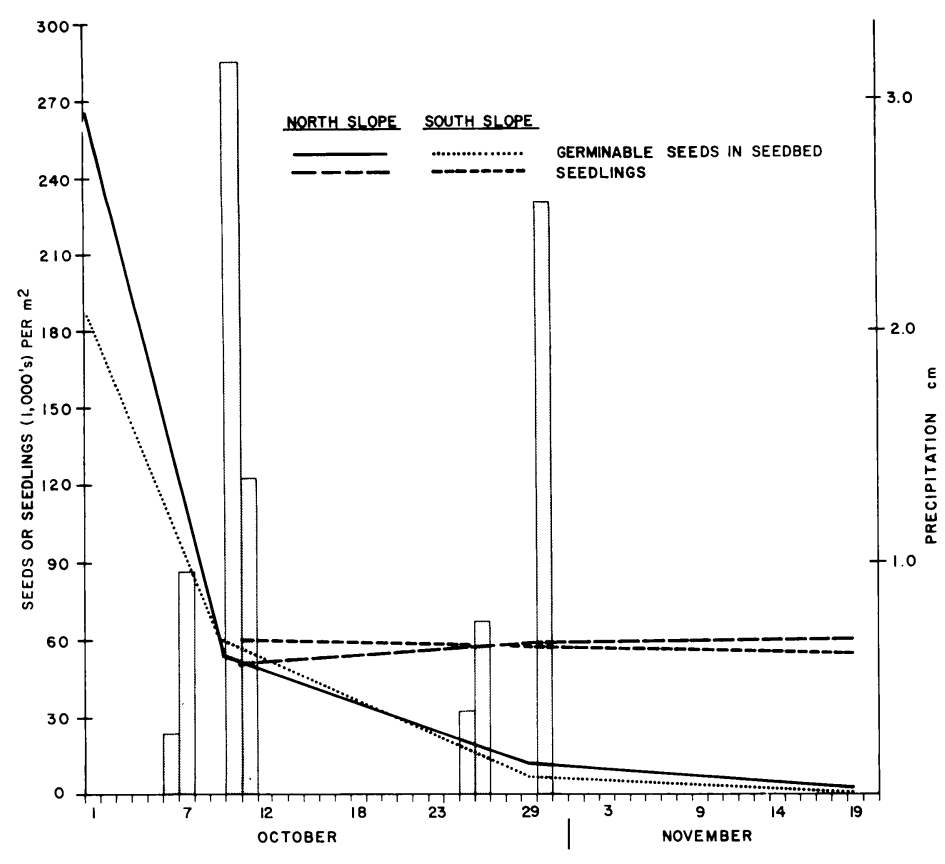

Fig. 3a. Germinable seeds in litter and soil, seedlings in field seedbed, and moisture events during initial germination period in October and November, 1975, at Sierra Foothill Range Field Station. Seeds were produced in a wet growing season.

after the initial rain (Tables $7 \mathrm{a}$ and $\mathrm{b}$ ). There appeared to be a large germinable seed reserve, because the germination test period was 8 weeks long and the afterripening requirements of Taeniatherum asperum had been satisfied by the end of the test. This experimental procedure created the appearance of a much greater germinable seed reserve for $T$. asperum by October 1 than was real. This was the only abundant species in which this interaction of the germination test with afterripening was apparent in October.

Trifolium hirtum was the second most important species because of 1) its abundance, 2) its large contribution to the germinable seed reserve carried from one year to the next, and 3) its economic importance in range improvement practices. On the south slope, there was a steady decline in both the germinable seeds and established seedlings of this species after the initial rain (Table $7 \mathrm{~b}$ ). On the north slope, the germinable seeds declined after the initial rain, but seedling establishment increased through the fifth week after the initial rain (Table $7 \mathrm{a})$.

A third key species was Erodium botrys. This species accounted for 5 to 10 percent of the germinable seeds on the two slopes (Tables $7 \mathrm{a}$ and b). Erodium botrys had almost total commitment of all seed reserves the first week after the initial rain. This species is noted as one of the first to germinate in these communities (Young, Evans, and Kay, 1975). After the first rain, 35 percent of the October 1 germinable seed reserve on the north slope was accounted for as germinable seeds or established plants with only 0.3 percent of the October 1 reserve remaining as germinable seeds (Table 7a).

On the south slope, the density of Erodium botrys established the first week after the initial rain actually exceeded by 100 plants $/ \mathrm{m}^{2}$ the germinable seed density estimated from germination tests on October 1, 10 days earlier. This seedling establishment 


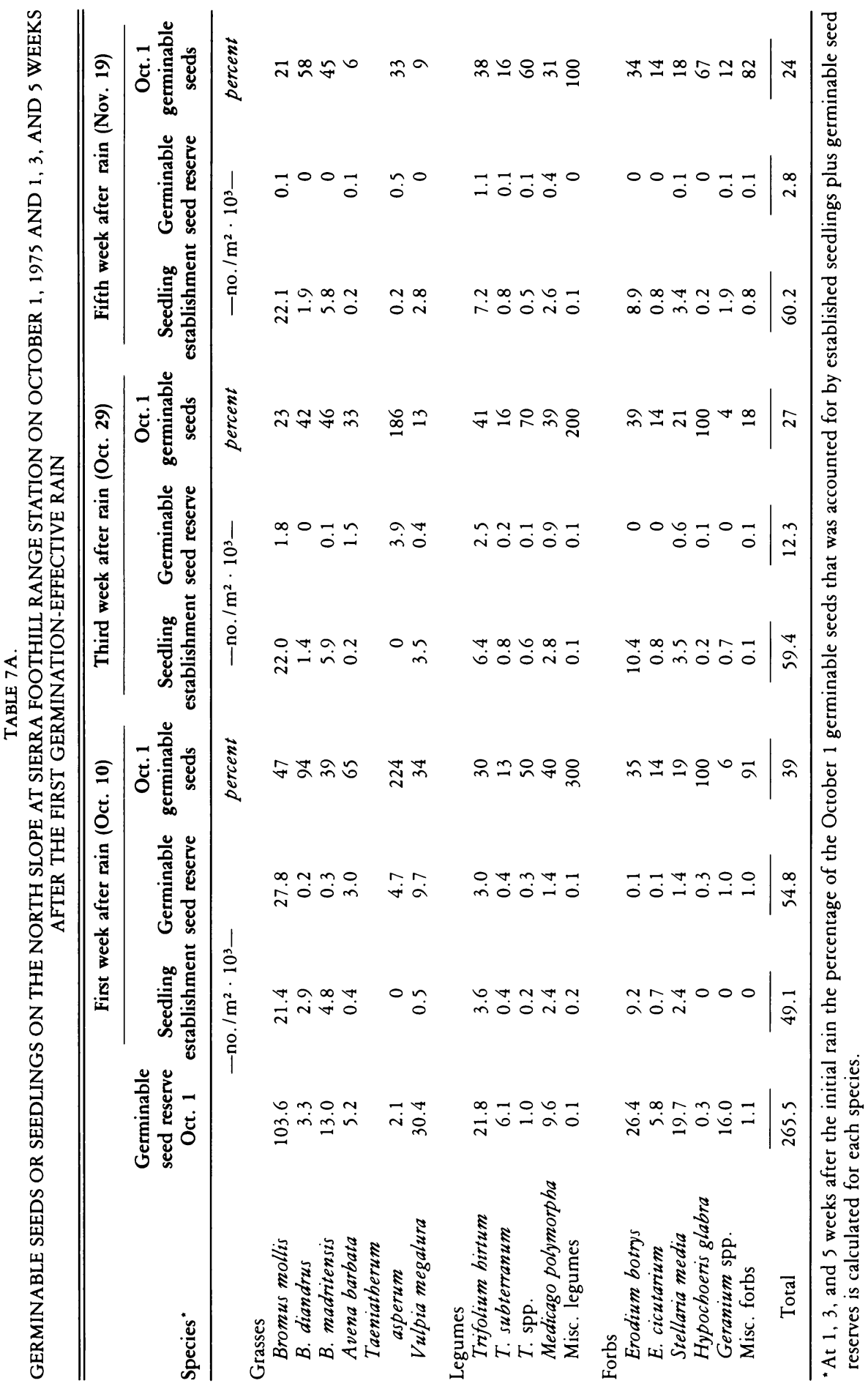




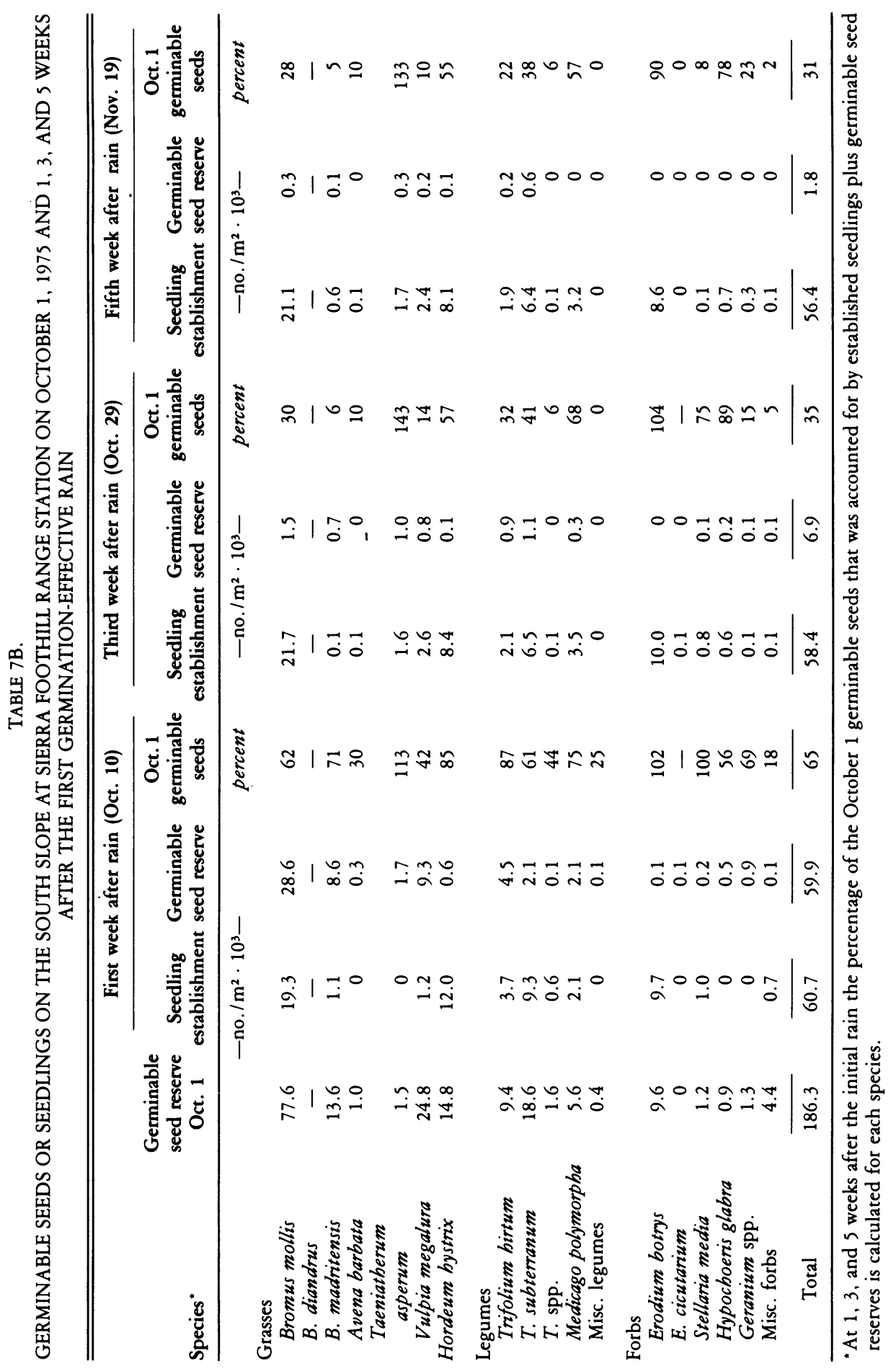


maintained itself through 5 weeks after the initial rain with only a slight drop in density, leaving 90 percent of the germinable seeds on October 1 accounted for by established seedlings.

There was relatively close agreement in 1975 in percentage species composition based on the germinable seed reserve before the first effective rain and the actual seedling establishment 5 weeks after the initial rain (Table 8a). For Bromus mollis the agreement was particularly close. On both slopes, Vulpia megalura Rydb., with quite small caryopses, contributed a much smaller percent composition than would be expected from the relative abundance of germinable seeds. Coefficients of determination for the relation between germinable seeds on October 1 and species composition 5 weeks after the initial rain indicated that variation in germinable seed population accounted for 90 percent and 81 percent of the variation in species composition on the north and south slopes, respectively. (Table $8 \mathrm{~b}$ ).

1976: Seed produced and germinated in a dry year. The winter of 1976-77 was exceptionally dry on the California annual ranges. The experimental area (SFRFS) received only 36 percent of normal precipitation. The timing of this precipitation was especially adverse for plant establishment. Rains occurred in August (Table 1) and did not initiate germination. The next rain $(2.23 \mathrm{~cm})$ was on September 2 (Fig. $3 \mathrm{~b}$ ) and was sufficient to initiate germination (Tables $9 \mathrm{a}$ and $\mathrm{b}$ ). Rain did not occur again until November 11 to 13 , when $2.5 \mathrm{~cm}$ fell. The dry period between September and November resulted in the loss of 74 and 86 percent of the seedlings that had germinated.

Seed production as indexed by bioassay samples was much reduced by the drought in $1975-76$, so the germinable seed reserve in 1976 was only 20 to 23 percent of that in 1975. Of this reduced germinable seed reserve, 23 to 28 percent, depending on aspect, was lost by the early germination and prolonged drought.

The mid-November rains in 1976 were ineffective because low temperature limited additional germination. By 3 weeks after these November rains, 6,200 plants $/ \mathrm{m}^{2}$ were established on the north slope and $12,700 / \mathrm{m}^{2}$ on the south slope (Tables 9a and b). The higher seedling density on the south slope was due to increased establishment of Bromus mollis and Trifolium subterraneum on this slope.

The first week after the September rains, 71 and 52 percent of the August 1 germinable seed reserve of Bromus mollis were present on the north and south slopes, respectively (Tables 9a and b). By the fifth week after the September rain, only 14 and 50 percent of the $B$. mollis remained on the north and south slopes, respectively. Thus, more $B$. mollis seeds were available to germinate on the south slope than on the north when the November rains occurred. What caused the greater loss of germinable seeds on the north slope compared to the south is not known. Usually, a given amount of moisture is more effective for supporting germination and plant growth on the north than on the south slope (Evans, Kay, and Young, 1975). This was not the case, however, in September, 1976, when 300 B. mollis seedlings $/ \mathrm{m}^{2}$ established on the north slope and 2,100 on the south. Most of these seedlings subsequently died in the October drought.

The largely buried fruits of Trifolium subterraneum fared better than seeds of Bromus mollis during the fall of 1976 on the south slope. Trifolium subterraneum is better adapted to the south than the north slope at this location, as is reflected in the initial germinable seed reserves of 8,100 (T. subterraneum) and 1,200 seeds (B. mollis) $/ \mathrm{m}^{2}$ (Tables $9 \mathrm{a}$ and $\mathrm{b}$ ). Very few of the $T$. subterraneum seeds germinated after the September rains, and germinable seed reserves actually increased during October, presumably as previously dormant seeds became germinable. 


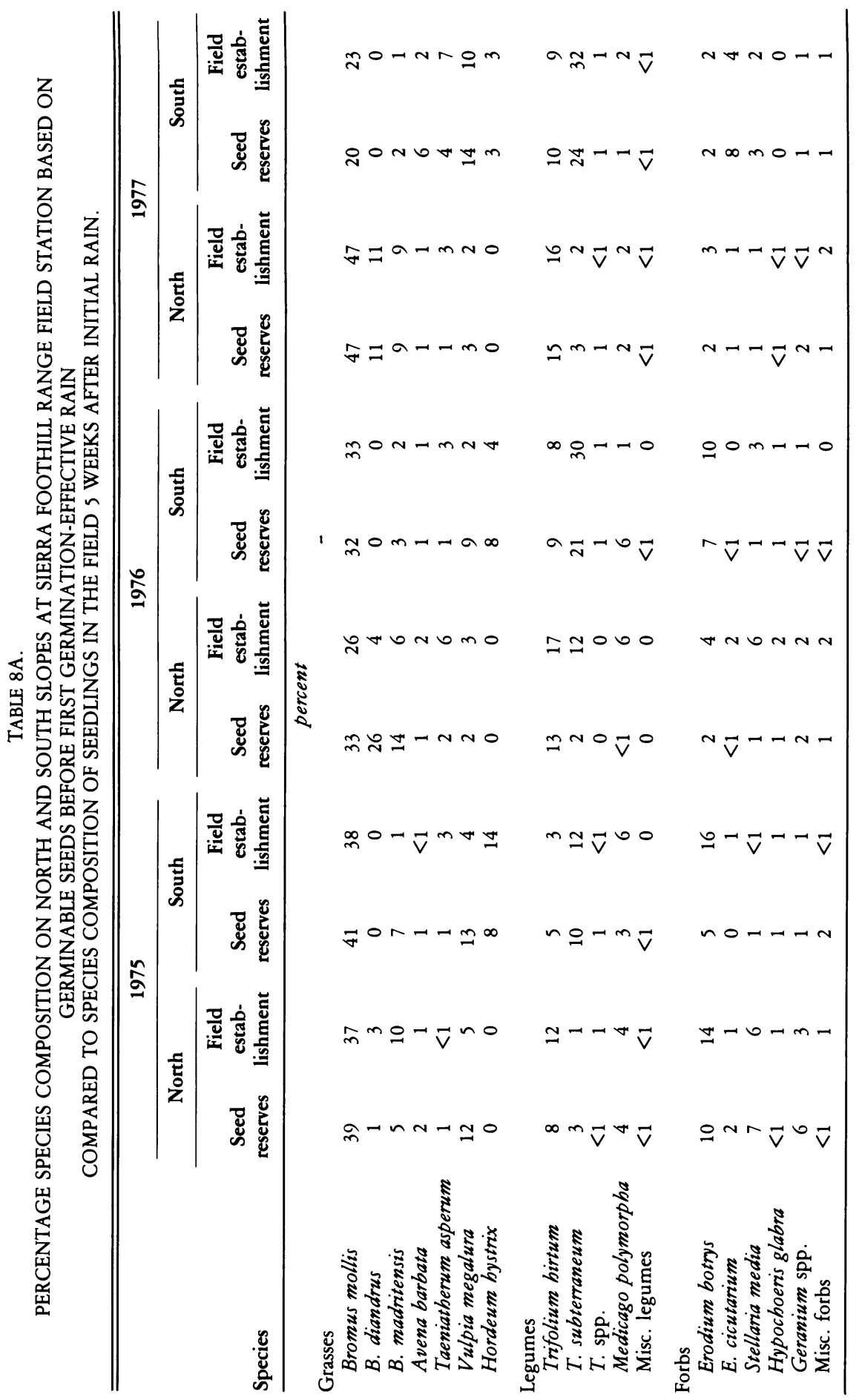


TABLE $8 \mathrm{~b}$.

COEFFICIENTS AND CONSTANTS FOR PARTIAL REGRESSION EQUATIONS $[\hat{y}=a+b(x)]$ FOR RELATIONSHIP BETWEEN GERMINABLE SEED RESERVES ON OCTOBER 1 AND SEEDLING ESTABLISHMENT 5 WEEKS AFTER INITIAL RAIN, AND ESTABLISHED PLANTS NEXT SPRING (1975-77, SIERRA FOOTHILL RANGE FIELD STATION).

\begin{tabular}{|c|c|c|c|c|c|c|}
\hline \multirow[b]{2}{*}{ Year and slope } & \multicolumn{3}{|c|}{$\begin{array}{l}\text { Regression of seedling establishment } \\
5 \text { weeks after initial rains } \\
\text { on Oct. } 1 \text { germinable seed reserves }\end{array}$} & \multicolumn{3}{|c|}{$\begin{array}{l}\text { Regression of established } \\
\text { plants the next spring } \\
\text { on Oct. } 1 \text { germinable seed reserves }\end{array}$} \\
\hline & $\mathbf{r}$ & a & b & $\mathbf{r}$ & a & b \\
\hline \multicolumn{7}{|l|}{1975} \\
\hline North slope & $0.95^{* *}$ & 0.26 & 0.21 & $0.86^{\star *}$ & 0.44 & 1.35 \\
\hline South slope & $0.90^{* *}$ & 0.43 & 0.26 & $0.96^{* *}$ & 5.91 & 2.62 \\
\hline \multicolumn{7}{|l|}{1976} \\
\hline North slope & $0.69^{*}$ & 0.23 & 4.87 & $0.83^{* *}$ & 0.98 & 1.10 \\
\hline South slope & $0.95 * *$ & -3.60 & 0.35 & $0.95 * *$ & -3.51 & 0.13 \\
\hline \multicolumn{7}{|l|}{1977} \\
\hline North slope & $0.99^{* *}$ & -2.30 & 0.74 & $0.97^{* *}$ & -2.55 & 0.32 \\
\hline South slope & $0.94^{\star \star *}$ & -8.49 & 0.68 & $0.86^{* *}$ & 1.21 & 9.01 \\
\hline All north slopes & $0.88^{\star *}$ & 0.329 & 0.211 & $0.93^{* *}$ & 6.90 & 1.33 \\
\hline All south slopes & $0.91^{* *}$ & 0.280 & 0.267 & $0.90^{* *}$ & 5.80 & 0.75 \\
\hline
\end{tabular}

* Significance at the 0.05 level of probability.

" Significance at the 0.01 level of probability.

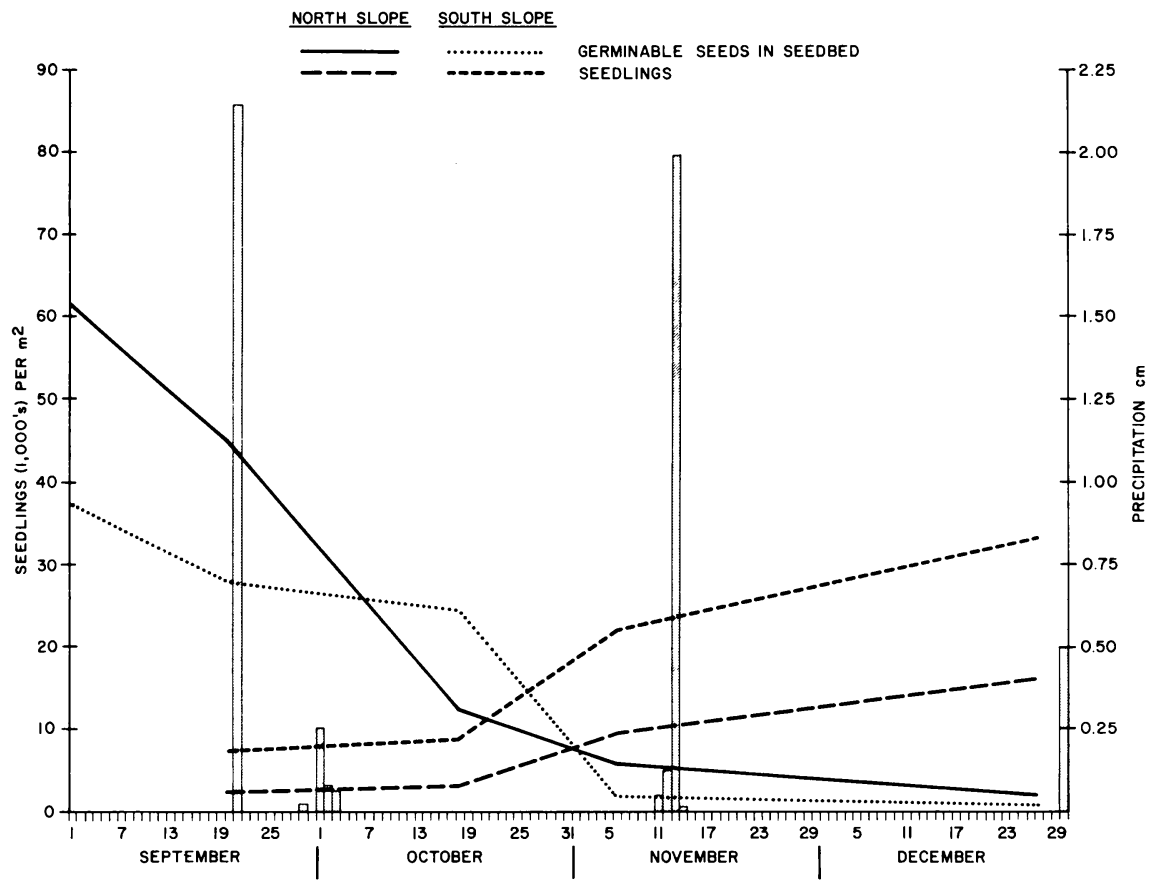

Fig. 3b. Germinable seeds in litter and soil, seedlings in field seedbeds, and moisture events during initial germination period in October, November, and December, 1976, at Sierra Foothill Range Field Station. Seeds were produced in a dry growing season. 


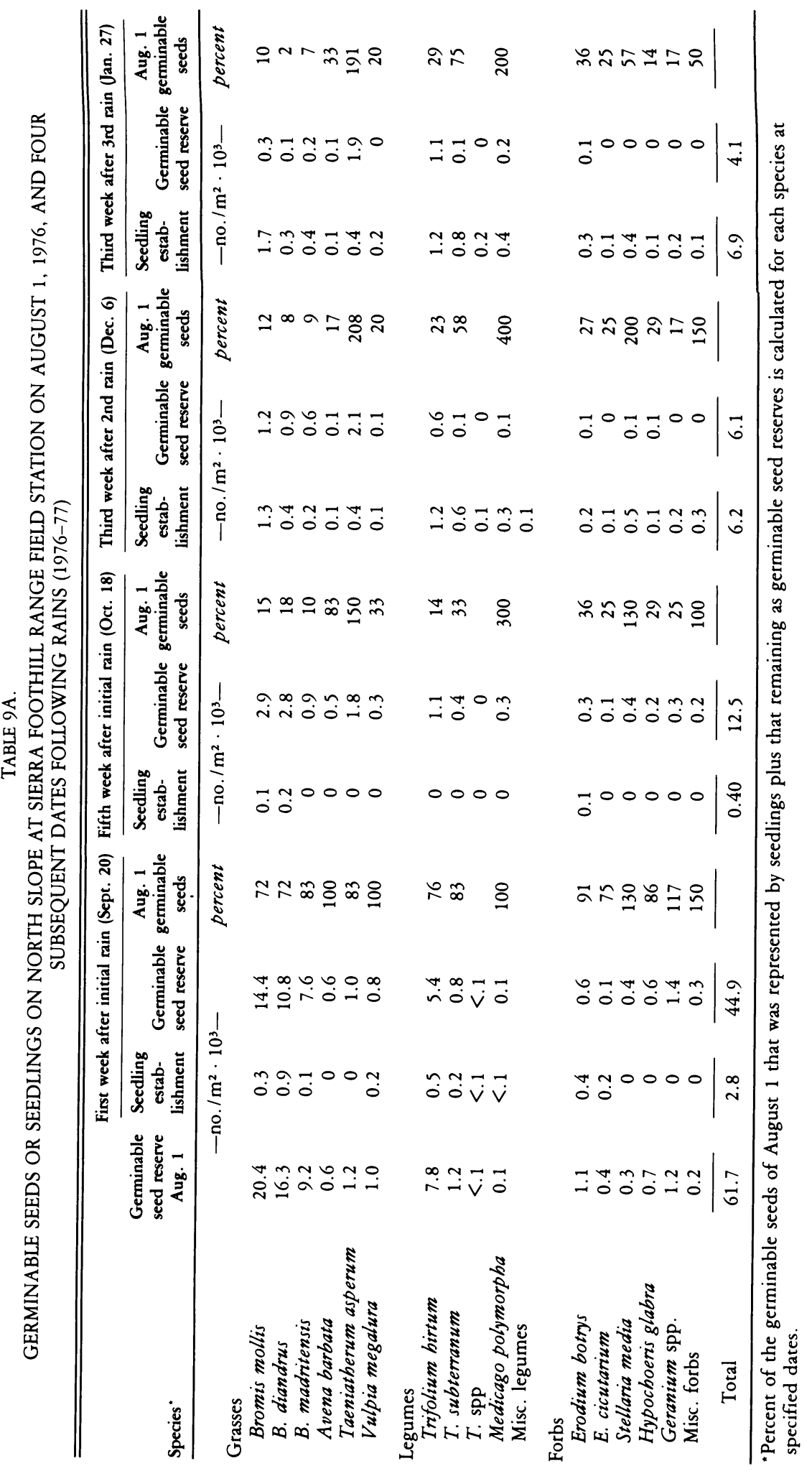




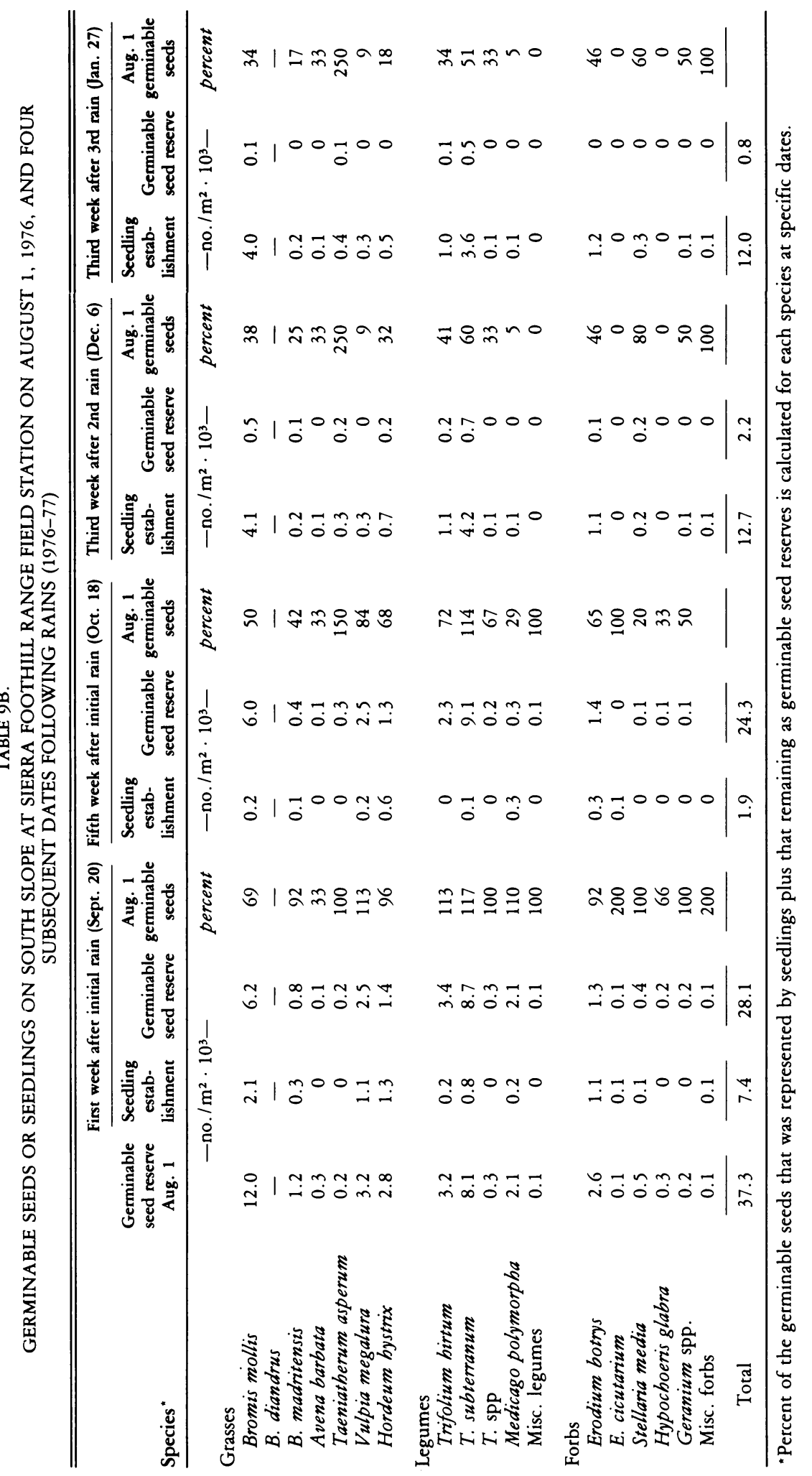


Species composition. Despite the significant $(P=0.01)$ decrease in density of the major species (Table 5) in 1976 compared to 1974 or 1975, the relative species composition remained similar. The relative abundance of Bromus mollis decreased on the north slope and that of legumes increased on both slopes (Table 8a). Apparently, the hardseeded legumes enjoy an adaptive advantage when the germination period is marked by dry and wet periods. To interpret these changes correctly, one must remember that the legumes were increasing their relative dominance in the community at the same time that their total density was being drastically reduced.

Erodium botrys decreased in species composition in 1976, especially on the north slope (Table $8 \mathrm{a}$ ). Because of the germination pattern of this species, it is particularly susceptible to conditions producing early germination and subsequent desiccation. However, established E. botrys seedlings can withstand long periods of drought. Some of the $E$. botrys seedlings that established after the August rains of 1975 survived until October rains occurred (Raguse, Young, and Evans, 1977).

Despite the 5-month period (September to January) of sporadic rain, intervening drought, and fluctuating seedbed temperatures, a substantial reserve of germinable seeds remained in January, 1977 (Tables 9a and b). Germinable seeds totaled $800 / \mathrm{m}^{2}$ on the south slope and $4,100 / \mathrm{m}^{2}$ on the north. A large portion of the germinable seeds on the north slope were those of Taenatherum asperum, whose seedlings increased from a trace in 1976 to 6 percent of the seedling population in 1977 (Table 8a).

In 1976, there was a good relation between proportions of germinable seeds and ultimate species composition on the south slope $(\mathrm{P}=0.01)$, for which 90 percent of the variation was accounted for by variation in the seed reserve (Table $8 \mathrm{~b}$ ). On the north slope, only 48 percent of this variation could be attributed to variation in the population of germinable seeds $(P=0.05)$. For both slopes, in 1976 , the relationship between germinable seeds on October 1 and composition of the plant community the next spring was statistically significant $(\mathrm{P}=0.01)$ (Table $8 \mathrm{~b})$.

The January 1977 levels of germinable seeds (Tables 9a and b) amounted to 65 percent of the germinable reserves noted 5 weeks after the initial rain in 1975 (Tables 7a and b), even though the initial reserves were 4.6 times as great in 1975 as in 1976 $\left(225,900\right.$ versus $\left.49,500 / \mathrm{m}^{2}\right)$. Seedling establishment in $1976-77$ was 16 percent of that observed in $1975-76$.

1977: Seed produced in a dry year and germinated in a wet year. The fall of 1977 was similar to that of 1976, with rain in September and then a dry October (Table 1). The September rains totaling $1.7 \mathrm{~cm}$, fell on September 19 and 20, when seedbed temperatures were high, and they failed to initiate germination. The next rain $(0.3 \mathrm{~cm})$ occurred October 27 through 31 (Fig. 3c) and again failed to trigger germination. On November $6,2.2 \mathrm{~cm}$ of rain fell and produced germination (Fig. $3 \mathrm{c}$ ).

One week after the November rain, 55 percent of the seed reserve on the north slope and 51 percent of that on the south slope were converted to established seedlings (Tables $10 \mathrm{a}$ and $\mathrm{b}$ ). Germinable seed reserves and established seedlings accounted for 85 and 88 percent of the October 1 germinable seed reserve on the north and south slopes, respectively. Th a comparable germination period in 1975 , the first week after the initial rain, 39 and 65 percent of the October 1 germinable seed reserves were accounted for by seedlings and germinable seed on the north and south slopes, respectively. (Tables 7a and $b$ ). After the 2 years of drought, the October 1, 1977, germinable seed reserves were only 11 percent of those of 1975 , the production year before the drought. Seedling 


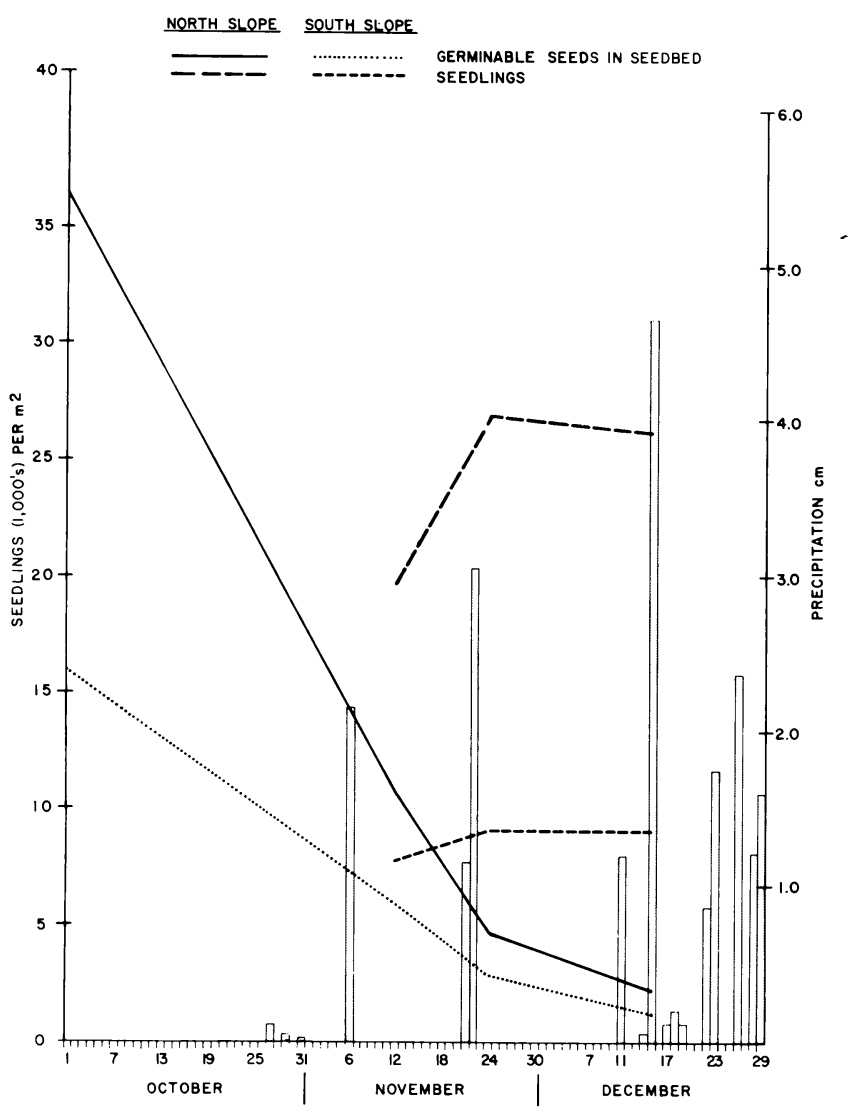

Fig. 3c. Germinable seeds in litter and soil, seedlings in field seedbeds, and moisture events during initial germination period in October, November and December, 1977, at Sierra Foothill Range Field Station. Seeds were produced in a dry growing season.

establishment in 1977,1 week after the initial rain, was 25 percent of the density for the comparable period in 1975 .

The percentage of germinable Bromus mollis seeds that became established plants in 1977 was 74 percent on the north slope and 73 percent on the south slope (Tables 10a and $b$ ). The percentage that established was lowest, 10 percent, on the north slope in 1976 and was 21 and 28 percent on the north and south slopes, respectively, in the drought year of 1975 . By 5 weeks after the initial rain in 1977 , the number of germinable $B$. mollis seeds had declined to $100 / \mathrm{m}^{2}$ on both slopes (Tables $10 \mathrm{a}$ and $\mathrm{b}$ ).

Trifolium hirtum, another key species, reacted differently on the two slopes during the recovery year. On the north slope, established seedlings and germinable seeds recovered 3 weeks after the initial rain equaled 142 percent of the October 1 seed reserve (Table 10a). Five weeks after the initial rain, 100 percent of the germinable seed reserve was accounted for by seedlings or germinable seeds. On the south slope, where $T$. hirtum was relatively less important in species compositon, the recovery of seedlings and germinable seeds was less than it was on the north slope.

On the north slope in 1977 , only 11 percent of the October 1 germinable seed reserve of Erodium botrys remained as germinable seeds 1 week after the initial rain (Table 10a). By 3 weeks after the initial rain, the seed reserves of this species had disappeared on both slopes. 


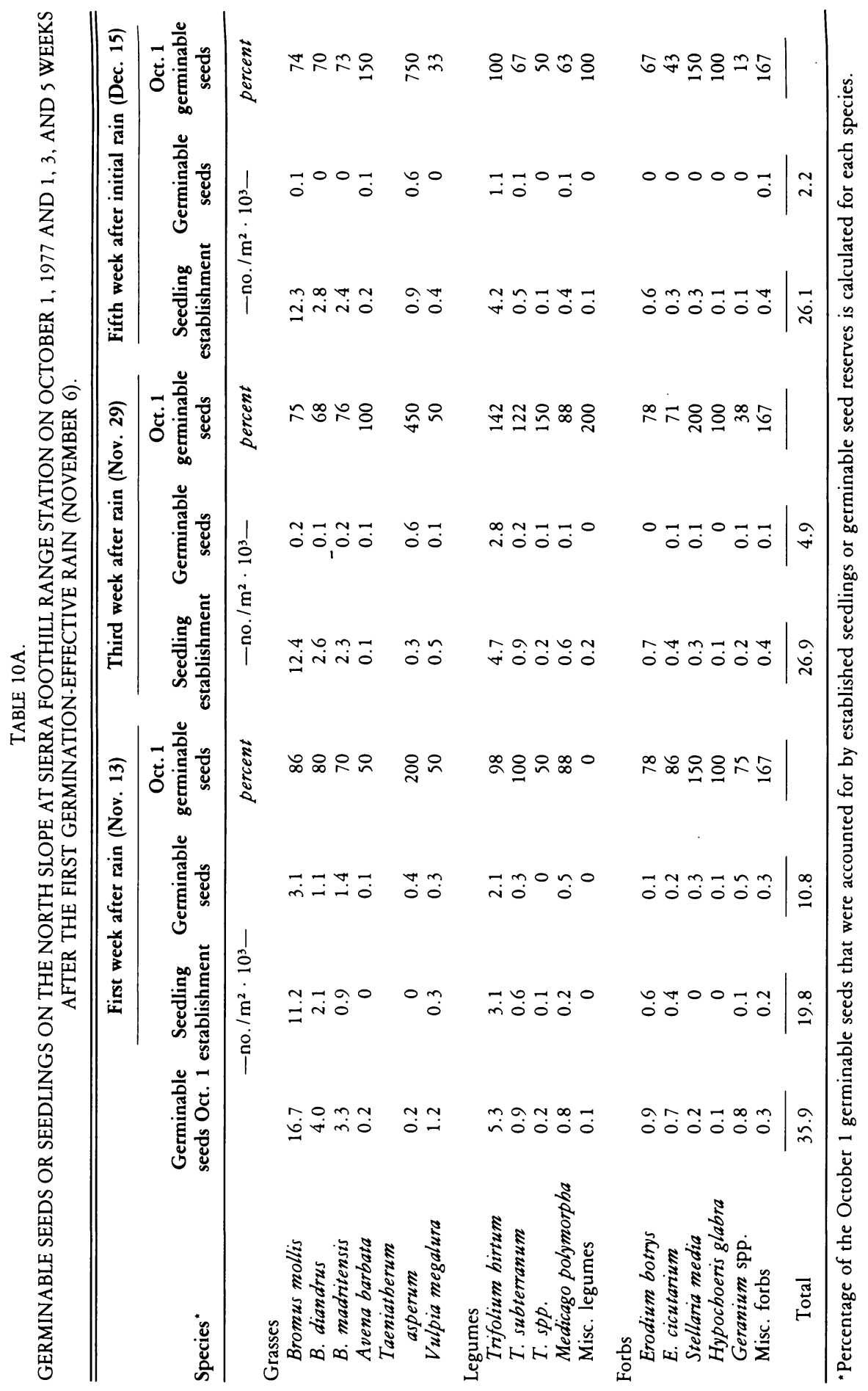




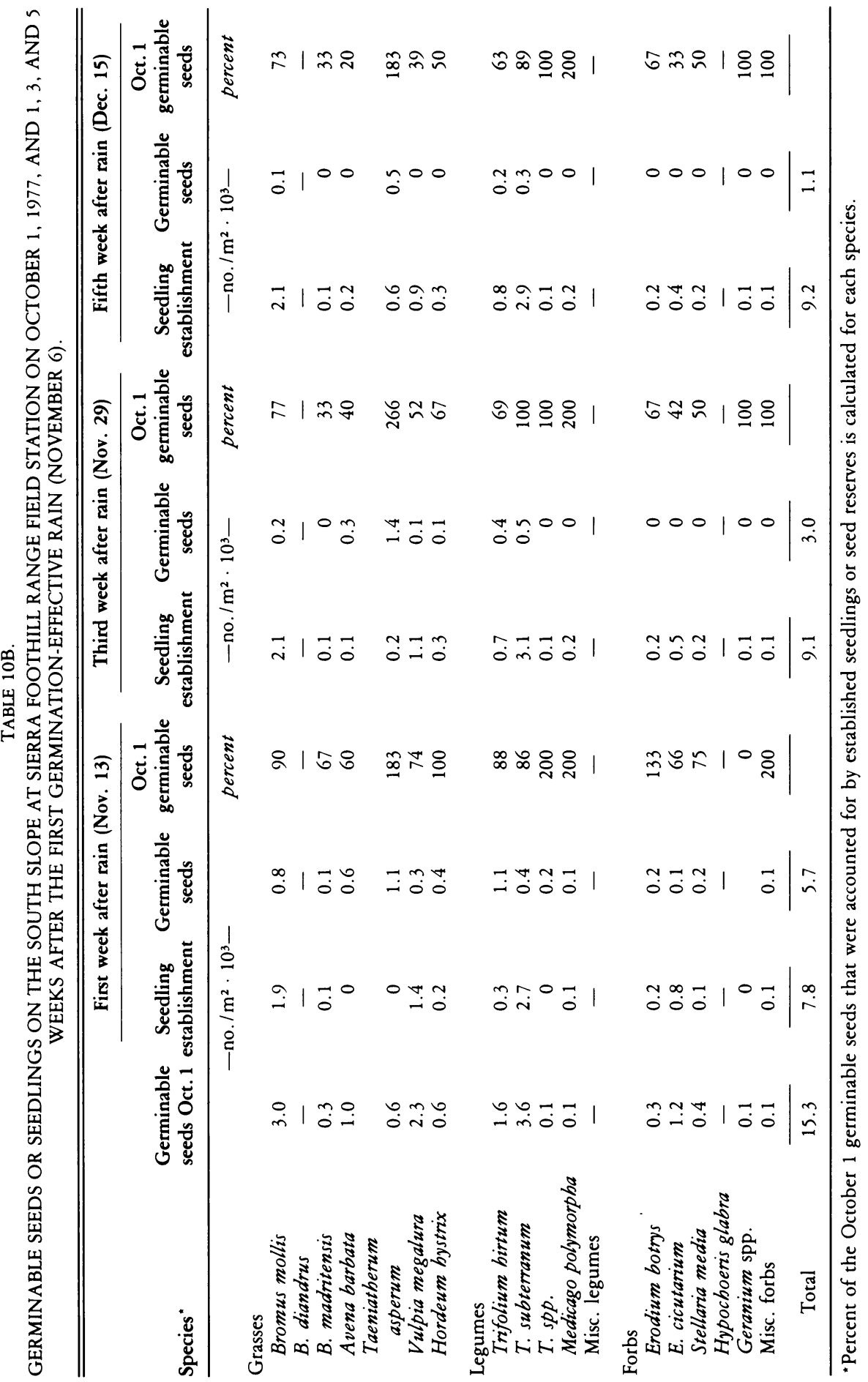


On the north slope, there was near perfect agreement between species composition of germinable seeds on October 1 and of seedling establishment $(P=0.01)$, with 98 percent of the variation in established plants accounted for by the variation in seed reserves $($ Table $8 b)$. For the south slope the $\mathrm{r}^{2}$ value $(\mathrm{P}=0.01)$ was slightly lower, 88 percent. Trifolium subterraneum contributed 8 percent more to the species composition of the established flora than to the germinable seed reserve on the south slope. This difference probably accounts for some of the increased variation (Table 8a).

Again, for both slopes there was a significant $(P=0.01)$ relationship between the germinable seeds on October 1 and the species composition of the subsequent plant community the next spring (Table $8 \mathrm{~b}$ ).

\section{Germination periodicity in bioassay samples}

The periodicity of germination in the bioassay samples can be used as an index of the dormancy characteristics and rate of germination of seeds (Young and Evans, 1975).

Bromus mollis. Seeds of $B$. mollis from samples collected in December, well after the initial fall flush of germination, had periodicity of germination similar to that of seeds from samples collected the next April (Fig. 4a). These are the seeds that carry over from

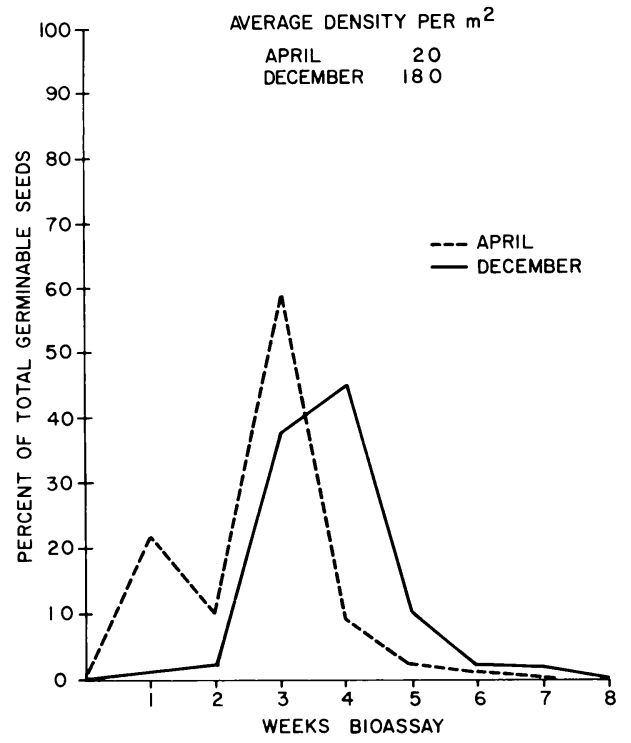

Fig. 4a. Periodicity of germination of Bromus mollis seeds during 8 weeks of bioassay. Percentage of total germination was calculated from mean germination of samples collected from the north slope at the Sierra Foothill Range Field Station in 1974 through 1977. December and April samples contained seed reserves carried from one season to the next. Average densities of seedlings $/ \mathrm{m}^{2}$ are shown on figure.

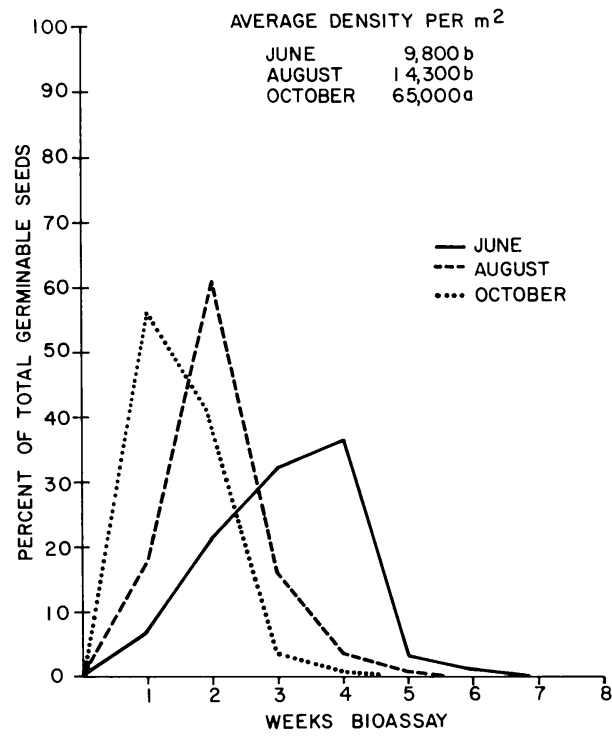

Fig. 4b. Periodicity of germination of Bromus mollis seeds during 8 weeks of bioassay. Percentage of total germination was calculated from mean germination of samples collected from the north slope at the Sierra Foothill Range Field Station in 1974 through 1977. June, August, and October samples contained the current year's seed production plus residual seeds from the previous season. Average densities of seedlings $/ \mathrm{m}^{2}$ are shown on figure. Seedling density means followed by the same letter are not significantly different at the 0.01 level of probability, as determined by Duncan's multiple range test. 
one season to the next. Somehow the seedbed environment of these seeds, during the initial flush of germination, induced dormancy, even though there is no evidence that the seeds were inherently dormant before the germination period. Seeds of $B$. mollis from the December or April collections germinated relatively slowly, with peak germination occurring the third or fourth week of the test. However, germination reached a definite peak, in contrast to the prolonged, continuous germination of seeds that have environmentally acquired physiologic dormancy (Young and Evans, 1975).

With the current year's production of $B$. mollis seed, the germination potential of the test samples steadily increased from June through October (Fig. 4b). Besides the increasing percentages of germinable seeds, the periodicity of germination became more rapid during the summer, with the peak germination moving from 4 weeks of testing in June, to 2 weeks in August, to 1 week in October (Fig. 4b).

Trifolium birtum. The percentage of germinable residual seeds of $T$. birtum (Fig. 5a) was greater than that of $B$. mollis (Fig. 4a). However, seeds from December and April samples had definite peaks in germination that occurred later than but were similar to those observed for $B$. mollis. Over the 4 years of this study, there was a significant $(\mathrm{P}=0.01)$ annual decline in germinable seeds of $T$. hirtum from December to April.

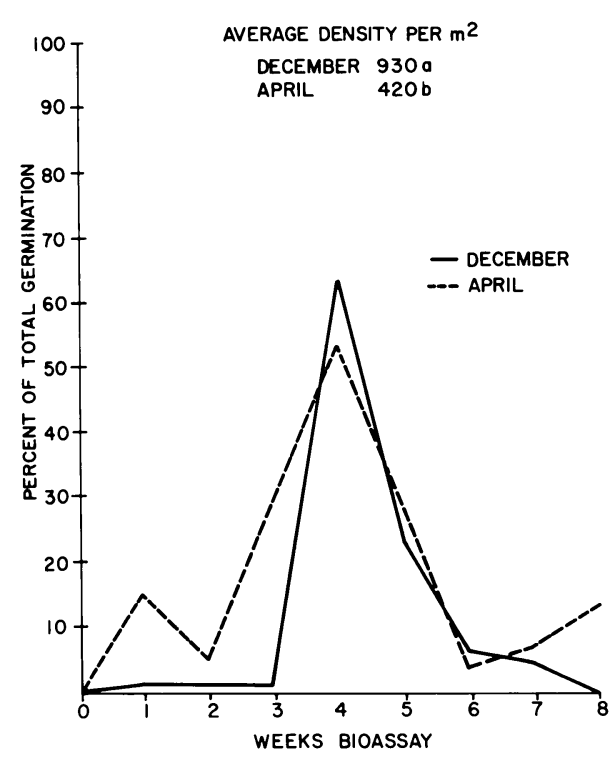

Fig. 5a. Periodicity of germination of Trifolium hirtum seeds during 8 weeks of testing. Percentage of total germination was calculated from mean germination of samples collected from the north slope at the Sierra Foothill Range Field Station in 1974 through 1977. December and April samples contained seed reserves carried from one season to the next. Average densities of seedlings $/ \mathrm{m}^{2}$ are shown on figures. Seedling density means followed by the same letter are not significantly different at the 0.05 level of probability, as determined by Duncan's multiple range test.

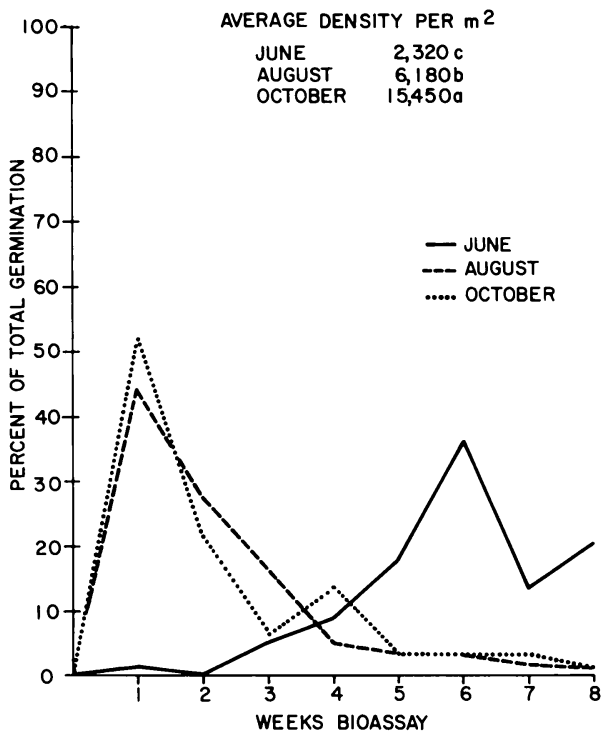

Fig. Sb. Periodicity of germination of Trifolium hirtum seeds during 8 weeks of testing. Percentage of total germination was calculated from mean germination of samples collected from the north slope at the Sierra Foothill Range Field Station in 1974 through 1977. June, August, and October samples contained the current year's seed production plus residual seeds from the previous season. Average densities of seedlings $/ \mathrm{m}^{2}$ are shown on figure. Seedling density means followed by the same letter are not significantly different at the 0.01 level of probability, as determined by Duncan's multiple range test. 
In June, when the current year's seed production had just started to disperse to the seedbed, the peak in germination of $T$. hirtum seeds occurred after 6 weeks of testing (Fig. 5b). In contrast, in August and October the peak germination of this species occurred in the first week of the test.

Erodium botrys. We do not show germination periodicity for $E$. botrys from December and April collections, because this species was not detected until after the initial flush of germination in the fall. The seeds of this species have a positive dispersal and self-burial system that virtually assures germination, although it may not assure establishment. This phenomenon suggests that the nondormant seeds of other species that germinated in midwinter and spring samples must have been in a field environment that inhibited germination.

The germination pattern for $E$. botrys in June after seed dispersal had two peaks, one after 1 week of testing and the other after 6 weeks (Fig. 6). However, the density of seedlings of this species averaged annually only 2 percent of that in October. By August, seedling density had increased significantly $(P=0.01)$ to about 40 percent of that noted

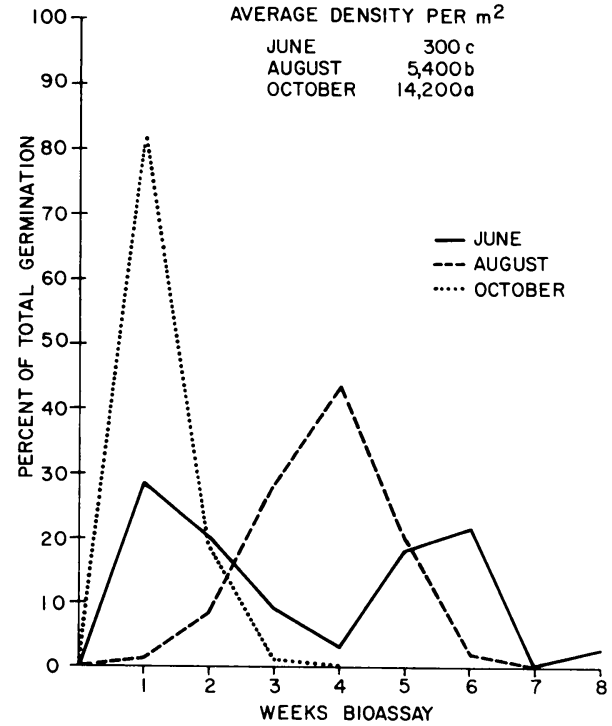

Fig. 6. Periodicity of germination of Erodium botrys seeds during 8 weeks of testing. Percentage of total germination was calculated from mean germination of samples collected from the north slope at the Sierra Foothill Range Field Station in 1974 through 1977. June, August, and October samples contained only the current year's seed production because this species has no detectable carryover of seeds from the previous year. Average densities of seeds $/ \mathrm{m}^{2}$ are shown on figure. Seedling density means followed by the same letter are not significantly different at the 0.01 level of probability as determined by Duncan's multiple range test.

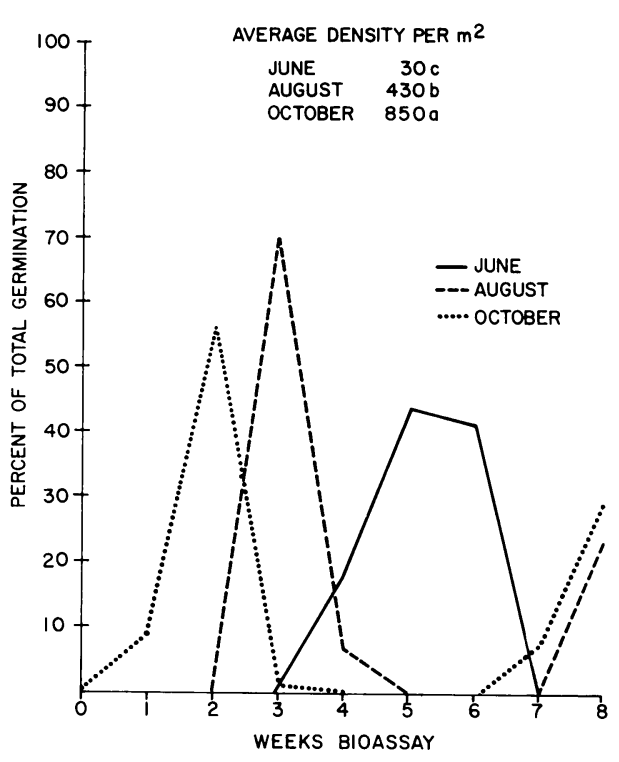

Fig. 7. Periodicity of germination of Taeniatherum asperum seeds during 8 weeks of testing. Percentage of total germination was calculated from mean germination of samples collected from the south slope at the Sierra Foothill Range Field Station in 1974 through 1977. June, August, and October samples contained the current year's seed production plus residual seed from the previous year. Average seedling densities $/ \mathrm{m}^{2}$ are shown on the figure. Seedling density means followed by the same letter are not significantly different at the 0.01 level of probability, as determined by Duncan's multiple range test. 
in October, and the peak germination had shifted to 4 weeks of testing. In October, 82 percent of the germinable seeds of $E$. botrys germinated during the first week of bioassay (Fig. 6).

Taeniatherum asperum. Taeniatherum asperum comprised a relatively small portion of the total reproductive potential; however, its reproductive strategy appeared markedly different from those of the other annual grass species (Fig. 7). In June there was virtually no detectable germinable reproductive reserve of this species. The few germinable seeds that were detected had delayed germination, with peaks at 5 and 6 weeks.

Germination peaks in August and October samples had shifted to 3 and 2 weeks, respectively, but there was additional germination at 8 weeks (Fig. 7). In contrast to the pattern for Bromus mollis, the initial peak in germination of $T$. asperum was in the first week of bioassay.

\section{Germination sequence-relation among species}

Annual grasslands in California are usually composed of a mosaic of species often occurring in small relatively pure patches. Erodium botrys often colonizes open places without litter. Areas with mulch or litter on the soil surface are dominated by grasses. Is this patchiness caused by the quality of the seedbed or the differential dispersal of the seeds? To test for randomness of dispersal, we analyzed by a correlation matrix the relationship among species germinating from each sample (Table 11). We used only one sample size, $6.25 \mathrm{~cm}^{2}$. We compared germination from samples collected October 1 , 1975,1976 , and 1977. On the north and south slopes, the highest positive correlation coefficients were obtained for the relation between Bromus mollis and B. madritensis L. These two grass species appeared to be relatively close ecological equivalents.

In contrast, there was a negative relationship between the germination of Bromus

TABLE 11.

CORRELATION MATRIX FOR DOMINANT SPECIES THAT GERMINATED FROM INDIVIDUAL $6.25-\mathrm{cm}^{2}$ BIOASSAY SAMPLES TAKEN OCTOBER 1, 1974-1977 AT SIERRA FOOTHILL RANGE FIELD STATION

\begin{tabular}{|c|c|c|c|c|c|}
\hline \multirow[b]{2}{*}{ Species } & \multicolumn{5}{|c|}{ Correlation coefficient ${ }^{*}$} \\
\hline & $\begin{array}{c}\text { Bromus } \\
\text { madritensis }\end{array}$ & $\begin{array}{c}\text { Erodium } \\
\text { botrys }\end{array}$ & $\begin{array}{l}\text { Trifolium } \\
\text { birtum }\end{array}$ & $\begin{array}{l}\text { Avena } \\
\text { barbata }\end{array}$ & $\begin{array}{c}\text { Taeniatherum } \\
\text { asperum }\end{array}$ \\
\hline \multicolumn{6}{|c|}{ South slope $(\mathrm{N}=388)$} \\
\hline $\begin{array}{l}\text { Bromus mollis } \\
\text { B. madritensis } \\
\text { Erodium botrys } \\
\text { Trifolium birtum } \\
\text { Avena barbata }\end{array}$ & 0.66 & $\begin{array}{l}-0.54 \\
-0.42\end{array}$ & $\begin{array}{l}-0.34 \\
-0.28 \\
-0.13\end{array}$ & $\begin{array}{r}0.46 \\
0.55 \\
-0.30 \\
-0.21\end{array}$ & $\begin{array}{l}-0.24 \\
-0.24 \\
-0.21 \\
-0.23 \\
-0.20\end{array}$ \\
\hline \multicolumn{6}{|c|}{ North slope $(\mathrm{N}=396)$} \\
\hline $\begin{array}{l}\text { Bromus mollis } \\
\text { B. madritensis } \\
\text { Erodium botrys } \\
\text { Trifolium hirtum } \\
\text { Avena barbata }\end{array}$ & 0.85 & $\begin{array}{l}-0.53 \\
-0.48\end{array}$ & $\begin{array}{l}-0.42 \\
-0.39 \\
-0.29\end{array}$ & $\begin{array}{r}0.51 \\
0.50 \\
-0.37 \\
-0.19\end{array}$ & $\begin{array}{l}-0.03 \text { n.s. } \\
-0.05 \text { n.s. } \\
-0.24 \\
-0.11^{\star} \\
-0.14\end{array}$ \\
\hline
\end{tabular}

-All correlation coefficients are significant at the 0.01 level of probability, except the ones followed by n.s. (nonsignificant) or * (significant at the 0.05 level of probability). 
mollis and that of Erodium botrys or Trifolium hirtum on both slopes. This suggests that where $B$. mollis seeds were concentrated, there were fewer seeds of the broadleaf dominants. However, these correlation coefficients are not very large, accounting for only about 25 percent of the variation in the $B$. mollis population. The relation between the grasses and $E$. botrys and $T$. birtum is complicated by the tendency for the two forbs to be negatively related.

Relationships of Avena barbata Pott ex Link with other species were similar to those of a Bromus mollis and $B$. madritensis. The aggressive colonizing grass Trifolium asperum tended to be negatively related to all species (Table 11 ).

We used a stepwise analysis to select combinations of species whose densities were most highly correlated, either positively or negatively, based on the sample populations (Draper and Smith, 1966). The initial comparison involved the single species (the independent variable $\mathrm{x}_{1}$ ) whose density was most highly correlated with that of another

TABLE 12.

STEPWISE VARIABLE SELECTION FROM REGRESSION FOR RELATIONSHIPS AMONG DOMINANT SPECIES* FROM INDIVIDUAL $6.25-\mathrm{cm}^{2}$ SAMPLES FROM THE NORTH SLOPE AT SIERRA FOOTHILL RANGE FIELD STATION

\begin{tabular}{|c|c|c|c|c|c|c|c|}
\hline \multirow[b]{2}{*}{$\mathbf{Y}$} & \multirow[b]{2}{*}{ no. } & \multicolumn{6}{|c|}{ Equation } \\
\hline & & $\mathbf{X 1}$ & X2† & X3† & X4千 & X5† & $\mathbf{r}$ \\
\hline $\begin{array}{l}\text { Brmo } \\
\text { (Bromus } \\
\text { mollis) }\end{array}$ & $\begin{array}{l}1 \\
2 \\
3 \\
4 \\
5\end{array}$ & $\begin{array}{l}\text { Brma + } \\
\text { Brma + } \\
\text { Brma + } \\
\text { Brma + } \\
\text { Brma + }\end{array}$ & $\begin{array}{l}\text { Erbo - } \\
\text { Erbo- } \\
\text { Erbo - } \\
\text { Erbo- }\end{array}$ & $\begin{array}{l}\text { Trhr - } \\
\text { Trhr - } \\
\text { Trhr - }\end{array}$ & $\begin{array}{l}\text { Brdi - } \\
\text { Brdi - }\end{array}$ & Avba + & $\begin{array}{l}0.90 \\
0.90 \\
0.90 \\
0.86 \\
0.85\end{array}$ \\
\hline $\begin{array}{l}\text { Erbo } \\
\text { (Erodium } \\
\text { botrys) }\end{array}$ & $\begin{array}{l}1 \\
2 \\
3 \\
4 \\
5\end{array}$ & $\begin{array}{l}\text { Trhr - } \\
\text { Trhr - } \\
\text { Brmo - } \\
\text { Brmo - } \\
\text { Brmo - }\end{array}$ & $\begin{array}{l}\text { Brmo - } \\
\text { Brmo - } \\
\text { Trhr - } \\
\text { Trhr - }\end{array}$ & $\begin{array}{l}\text { Brdi - } \\
\text { Brdi - } \\
\text { Brdi - }\end{array}$ & $\begin{array}{l}\text { Brma - } \\
\text { Brma - }\end{array}$ & Avba - & $\begin{array}{l}0.83 \\
0.83 \\
0.83 \\
0.78 \\
0.53\end{array}$ \\
\hline $\begin{array}{l}\text { Trhr } \\
\text { (Trifolium } \\
\text { birtum) }\end{array}$ & $\begin{array}{l}1 \\
2 \\
3 \\
4 \\
5\end{array}$ & $\begin{array}{l}\text { Erbo - } \\
\text { Erbo - } \\
\text { Brmo - } \\
\text { Brmo - } \\
\text { Brmo - }\end{array}$ & $\begin{array}{l}\text { Brmo - } \\
\text { Brmo - } \\
\text { Erbo - } \\
\text { Erbo - }\end{array}$ & $\begin{array}{l}\text { Brdi - } \\
\text { Brdi - } \\
\text { Brdi - }\end{array}$ & $\begin{array}{l}\text { Brma - } \\
\text { Brma - }\end{array}$ & Avba - & $\begin{array}{l}0.79 \\
0.79 \\
0.79 \\
0.74 \\
0.42\end{array}$ \\
\hline $\begin{array}{l}\text { Brma } \\
\text { (Bromus } \\
\text { madritensis) }\end{array}$ & $\begin{array}{l}1 \\
2 \\
3 \\
4 \\
5\end{array}$ & $\begin{array}{l}\text { Brmo + } \\
\text { Brmo + } \\
\text { Brmo + } \\
\text { Brmo + } \\
\text { Brmo + }\end{array}$ & $\begin{array}{l}\text { Brdi - } \\
\text { Brdi - } \\
\text { Avba + } \\
\text { Avba }+\end{array}$ & $\begin{array}{l}\text { Avba + } \\
\text { Avba + } \\
\text { Brdi - }\end{array}$ & $\begin{array}{l}\text { Erbo - } \\
\text { Erbo - }\end{array}$ & Trhr - & $\begin{array}{l}0.86 \\
0.86 \\
0.86 \\
0.85 \\
0.85\end{array}$ \\
\hline $\begin{array}{l}\text { Avba } \\
\text { (Avena } \\
\text { barbata) }\end{array}$ & $\begin{array}{l}1 \\
2 \\
3 \\
4 \\
5\end{array}$ & $\begin{array}{l}\text { Brma + } \\
\text { Brma + } \\
\text { Brma + } \\
\text { Brmo + } \\
\text { Brmo + }\end{array}$ & $\begin{array}{l}\text { Brdi }+ \\
\text { Brdi }+ \\
\text { Brdi }+ \\
\text { Brma }+\end{array}$ & $\begin{array}{l}\text { Brmo + } \\
\text { Brmo + } \\
\text { Brmo + }\end{array}$ & $\begin{array}{l}\text { Erbo - } \\
\text { Erbo - }\end{array}$ & Trhr - & $\begin{array}{l}0.55 \\
0.55 \\
0.54 \\
0.52 \\
0.51\end{array}$ \\
\hline $\begin{array}{l}\text { Brdi } \\
\text { (Bromus } \\
\text { diandrus) }\end{array}$ & $\begin{array}{l}1 \\
2 \\
3 \\
4 \\
5\end{array}$ & $\begin{array}{l}\text { Erbo - } \\
\text { Erbo - } \\
\text { Erbo - } \\
\text { Erbo - } \\
\text { Erbo - }\end{array}$ & $\begin{array}{l}\text { Trhr - } \\
\text { Trhr - } \\
\text { Trhr - } \\
\text { Trhr - }\end{array}$ & $\begin{array}{l}\text { Brma - } \\
\text { Brma - } \\
\text { Brma - }\end{array}$ & $\begin{array}{l}\text { Brmo - } \\
\text { Brmo - }\end{array}$ & Avba + & $\begin{array}{l}0.52 \\
0.51 \\
0.49 \\
0.31 \\
0.24\end{array}$ \\
\hline
\end{tabular}

* Samples collected October 1, 1974, 1975, 1976, and 1977.

I All correlation coefficients are significant at the 0.01 level of probability. Species arranged in descending order of $\mathrm{r}$ values. Sign following species either positive $(+)$ or negative $(-)$ correlation. $\mathrm{N}=396$. 
species (the dependent variable $y$ ). Then combinations of two to five species ( $x_{1}$ to $x_{5}$ ) were chosen whose combined densities were progressively more correlated with the dependent species. By this analysis, relationships of occurrence and density of the six dominant species on both north and south slopes at the SFRFS were ascertained (Tables 12 and 13).

On the north slope, among the other species, density of Bromus mollis was most highly correlated with that of other species (Table 12). The highest correlation of $B$. mollis with a single species was that with $B$. madritensis $(\mathrm{r}=0.85)$ and with a combination, that with $B$. madritensis (positive), E. botrys (negative) and $T$. hirtum (negative) $(\mathrm{r}=0.90)$. Densities of Erodium botrys, Trifolium hirtum, and $B$. diandrus were negatively correlated with those of all other species, singly or (except with Avena barbata) in combination, which indicates that those species has a strong tendency to

TABLE 13.

STEPWISE VARIABLE SELECTION FROM REGRESSION FOR RELATIONSHIPS AMONG DOMINANT SPECIES * FROM INDIVIDUAL $6.25-\mathrm{cm}^{2}$ SAMPLES FROM THE SOUTH SLOPE AT SIERRA FOOTHILL RANGE FIELD STATION

\begin{tabular}{|c|c|c|c|c|c|c|c|}
\hline \multirow{2}{*}{$\hat{\mathbf{Y}}$} & \multirow[b]{2}{*}{ no. } & \multicolumn{6}{|c|}{ Equation } \\
\hline & & X1† & X2† & X3† & X4t & X5t & $\mathbf{r}$ \\
\hline $\begin{array}{l}\text { Brmo } \\
\text { (Bromus } \\
\text { mollis) }\end{array}$ & $\begin{array}{l}1 \\
2 \\
3 \\
4 \\
5\end{array}$ & $\begin{array}{l}\text { Erbo - } \\
\text { Erbo - } \\
\text { Erbo - } \\
\text { Brma + } \\
\text { Brma + }\end{array}$ & $\begin{array}{l}\text { Tri- } \\
\text { Tri - } \\
\text { Brma + } \\
\text { Erbo - }\end{array}$ & $\begin{array}{l}\text { Teas - } \\
\text { Teas - } \\
\text { Tri- }\end{array}$ & $\begin{array}{l}\text { Brma + } \\
\text { Brma + }\end{array}$ & Avba + & $\begin{array}{l}0.85 \\
0.85 \\
0.77 \\
0.72 \\
0.66\end{array}$ \\
\hline $\begin{array}{l}\text { Erbo } \\
\text { (Erodium } \\
\text { botrys) }\end{array}$ & $\begin{array}{l}1 \\
2 \\
3 \\
4 \\
5\end{array}$ & $\begin{array}{l}\text { Teas - } \\
\text { Teas - } \\
\text { Brmo - } \\
\text { Brmo - } \\
\text { Brmo - }\end{array}$ & $\begin{array}{l}\text { Tri - } \\
\text { Tri - } \\
\text { Teas - } \\
\text { Teas - }\end{array}$ & $\begin{array}{l}\text { Brmo - } \\
\text { Brmo - } \\
\text { Tri - }\end{array}$ & $\begin{array}{l}\text { Brma - } \\
\text { Brma - }\end{array}$ & Avba - & $\begin{array}{l}0.84 \\
0.84 \\
0.84 \\
0.81 \\
0.54\end{array}$ \\
\hline $\begin{array}{l}\text { Trhr } \\
\text { (Trifolium } \\
\text { birtum) }\end{array}$ & $\begin{array}{l}1 \\
2 \\
3 \\
4 \\
5\end{array}$ & $\begin{array}{l}\text { Erbo - } \\
\text { Erbo - } \\
\text { Brmo - } \\
\text { Brmo - } \\
\text { Brmo - }\end{array}$ & $\begin{array}{l}\text { Teas - } \\
\text { Teas - } \\
\text { Erbo - } \\
\text { Erbo - }\end{array}$ & $\begin{array}{l}\text { Brmo - } \\
\text { Brmo - } \\
\text { Teas - }\end{array}$ & $\begin{array}{l}\text { Brma - } \\
\text { Brma - }\end{array}$ & Avba - & $\begin{array}{l}0.78 \\
0.77 \\
0.74 \\
0.52 \\
0.38\end{array}$ \\
\hline $\begin{array}{l}\text { Brma } \\
\text { (Bromus } \\
\text { madritensis) }\end{array}$ & $\begin{array}{l}1 \\
2 \\
3 \\
4 \\
5\end{array}$ & $\begin{array}{l}\text { Avba + } \\
\text { Brmo + } \\
\text { Brmo + } \\
\text { Brmo + } \\
\text { Brmo + }\end{array}$ & $\begin{array}{l}\text { Erbo - } \\
\text { Avba + } \\
\text { Avba }+\end{array}$ & $\begin{array}{l}\text { Teas - } \\
\text { Erbo - } \\
\text { Erbo - }\end{array}$ & $\begin{array}{l}\text { Tri- } \\
\text { Teas - }\end{array}$ & Brmo + & $\begin{array}{l}0.75 \\
0.72 \\
0.72 \\
0.72 \\
0.66\end{array}$ \\
\hline $\begin{array}{l}\text { Avba } \\
\text { (Avena } \\
\text { barbata) }\end{array}$ & $\begin{array}{l}1 \\
2 \\
3 \\
4 \\
5\end{array}$ & $\begin{array}{l}\text { Brma + } \\
\text { Brma + } \\
\text { Brma + } \\
\text { Brma + } \\
\text { Brma + }\end{array}$ & $\begin{array}{l}\text { Teas - } \\
\text { Brmo + } \\
\text { Brmo + } \\
\text { Brmo + }\end{array}$ & $\begin{array}{l}\text { Erbo - } \\
\text { Teas - } \\
\text { Teas - }\end{array}$ & $\begin{array}{l}\text { Tri - } \\
\text { Erbo - }\end{array}$ & Brmo + & $\begin{array}{l}0.58 \\
0.57 \\
0.57 \\
0.57 \\
0.55\end{array}$ \\
\hline $\begin{array}{l}\text { Teas } \\
\text { (Taeniatherum } \\
\text { asperum) }\end{array}$ & $\begin{array}{l}1 \\
2 \\
3 \\
4 \\
5\end{array}$ & $\begin{array}{l}\text { Erbo - } \\
\text { Erbo - } \\
\text { Brmo - } \\
\text { Brmo - } \\
\text { Brmo - }\end{array}$ & $\begin{array}{l}\text { Tri - } \\
\text { Tri - } \\
\text { Erbo- } \\
\text { Erbo - }\end{array}$ & $\begin{array}{l}\text { Brmo - } \\
\text { Brmo - } \\
\text { Tri - }\end{array}$ & $\begin{array}{l}\text { Brma - } \\
\text { Brma - }\end{array}$ & Avba - & $\begin{array}{l}0.77 \\
0.76 \\
0.72 \\
0.47 \\
0.24\end{array}$ \\
\hline
\end{tabular}

* Samples collected October 1, 1974, 1975, 1976, and 1977.

t Species arranged in descending order of $r$ values. Sign following species symbol indicates either positive $(+)$ or negative $(-)$ correlation. $N=388$.

All correlation coefficients are significant at the 0.01 level of probability. 
occur alone or to dominate sites on which they occurred. Densities of $A$. barbata and $B$. madritensis were closely correlated with that of $B$. mollis and with those of one another, which indicates that these grass species occur together.

On the south slope, density relations among dominant species were similar to those on the north slope, except that Trifolium asperum was a dominant species and its density was negatively correlated with those of all other species (Table 13).

The stepwise variable selection analysis, based on a relatively small sample area $(6.25$ $\mathrm{cm}^{2}$ ), indicated that many dominant species occurred singly or dominated specific areas on both slopes. The dominant grass species, Bromus mollis and B. madritensis, and to a lesser extent, Avena barbata showed affinity toward one another in their occurrence and density.

\section{Changes in species composition after two years of drought}

Although this study was not designed to measure the influence of 2 years of relatively severe drought on the annual rangeland communities, the occurrence of such a drought during the course of the study provided an opportunity to do so.

Interpretation of results was complicated by the failure of projected irrigation water deliveries for 1977 to reach the quantities needed to provide forage for the livestock herd at SFRFS during the summer of 1977 . The station had no choice but to sell the animals. Therefore, the communities were not grazed during the 1976-77 growing season. Herbage production was extremely low during the fall, winter, and early spring of this season and would have supported very few animals, but if the animals had remained they would probably have been forced to graze everything.

Comparing the species composition of the germinable seed reserve in 1974 to that of the established plant population in 1977 indicated no marked change for Bromus mollis on the north slope and a 23 percent decrease in its relative frequency on the south slope (Table 14).

The two major legume species, Trifolium hirtum and T. subterraneum, either remained about the same or markedly increased in per cent composition; $T$. hirtum increased most on the north and T. subterraneum, on the south. Erodium botrys was most reduced in composition after the drought on the north slope, the aspect where this species had been most important before the drought.

Relative frequency of all the grass species collectively increased 9 per cent on the north slope and decreased 25 per cent on the south (Table 14). The relative change on the north slope appeared to be closely related to caryopsis size. The species with large caryopses, such as Bromus diandrus, increased in relative frequency, while Vulpia megalura with the smallest caryopses, had the greatest reduction in relative frequency. On the south slope, conditions exceeded the survival potential of most of the grasses. Bromus mollis was most adversely affected by drought ( $23 \%$ loss). The greatest increase in per cent frequency $(7 \%)$ in Taeniatherum asperum, bodes badly for future range management, because $T$. asperum is the least desirable of the annual grasses. The effect of drought that apparently was most detrimental to the annual species was the premature germination starts followed by prolonged dry periods. Premature germination starts are particularly detrimental for Erodium botrys, the species with an adaptive propensity for rapid germination. A contrasting germination strategy is apparent for the legumes, where relatively high percentages of hard seeds insure the persistence of a reproductive reserve through more than one premature germination start. 
TABLE 14

COMPARISON OF PERCENT SPECIES COMPOSITION BASED ON GERMINABLE SEED RESERVES OCTOBER 1, 1974, AND ON ESTABLISHED PLANTS DECEMBER 15, 1977, AT SIERRA FOOTHILL RANGE FIELD STATION

\begin{tabular}{|c|c|c|c|c|c|c|}
\hline \multirow[b]{3}{*}{ Species } & \multicolumn{6}{|c|}{ Relative frequency } \\
\hline & \multicolumn{2}{|c|}{1974} & \multicolumn{4}{|c|}{1977} \\
\hline & North & South & North & Change & South & Change \\
\hline & \multicolumn{6}{|c|}{ percent } \\
\hline \multicolumn{7}{|l|}{ Grasses } \\
\hline Bromus mollis & 44 & 46 & 47 & +3 & 23 & -23 \\
\hline B. diandrus & 1 & 0 & 11 & +10 & 0 & 0 \\
\hline B. madritensis & 4 & 7 & 9 & +5 & 1 & -6 \\
\hline Avena barbata & 2 & 1 & 1 & -1 & 2 & +1 \\
\hline Taeniatherum asperum & 1 & $\mathrm{~T}$ & 3 & +2 & 7 & +7 \\
\hline Vulpia megalura & 12 & 15 & 2 & -10 & 10 & -5 \\
\hline Hordeum hystrix & 0 & 2 & 0 & 0 & 3 & +1 \\
\hline Total change & - & - & - & +9 & - & -25 \\
\hline \multicolumn{7}{|l|}{ Legumes } \\
\hline Trifolium hirtum & 10 & 7 & 16 & +6 & 9 & +2 \\
\hline T. subterraneum & 2 & 8 & 2 & 0 & 32 & +24 \\
\hline Trifolium spp. & $\mathrm{T}$ & 1 & $<1$ & 0 & 1 & 0 \\
\hline Medicago polymorpha & $<1$ & 3 & 2 & +2 & 2 & -1 \\
\hline Misc. legumes & $<1$ & $<1$ & $<1$ & 0 & $<1$ & 0 \\
\hline Total change & - & - & - & +8 & - & +25 \\
\hline \multicolumn{7}{|l|}{ Forbs } \\
\hline Erodium botrys & 11 & 5 & 3 & -8 & 2 & -3 \\
\hline E. cicutarium & 2 & $<1$ & 1 & -1 & 4 & +4 \\
\hline Stellaria media & 5 & $<1$ & 1 & -4 & 2 & +2 \\
\hline Hypochoeris glabra & $\mathrm{T}$ & 1 & $<1$ & 0 & 0 & -1 \\
\hline Geranium spp. & 4 & 1 & $<1$ & -4 & 1 & 0 \\
\hline Misc. forbs & 1 & 3 & 2 & +1 & 1 & -2 \\
\hline Total change & - & - & - & -16 & - & 0 \\
\hline
\end{tabular}

Inherent afterripening requirements protect Taeniatherum asperum seeds from premature germination and subsequent drought losses. This alternative germination strategy apparently is very effective for the persistence and increase of this grass species during drought. The shifts in species composition and the apparent adaptive advantages they reflect may or may not persist as the communities return to near-average moisture regimes. The recovery year, with reduced population densities and increased environmental potential per plant, may have led to outbreeding among members of largely self-pollinated species, as had been postulated by Stebbins (1957) and Allard (1965).

\section{San Joaquin Experimental Range}

Although we only have 1 year's data for comparison, the information from the SJER provides a valuable extension of our results from the SFRFS.

The ungrazed area at the SJER provided an environment completely different from those of the other sampling sites. This area was grazed lightly in 1971 and was fenced in 1972 to exclude livestock in order to provide an experimental site for the International Biological Program. In 1976-77, the plant communities of this site were dominated by tall annual grasses, especially Bromus diandrus. Litter of the tall grasses had built up a 
thick mulch layer on the soil surface in the ungrazed area. The drought was so severe $(23 \mathrm{~cm}$ total growing-season precipitation versus a mean of $75 \mathrm{~cm}$ ) that many of the grasses failed to flower and set seed. Coupled with intense competition among grasses was the considerable soil disturbance caused by the burrowing activities of a concentration of rodents apparently attracted by the grass and litter cover.

In contrast, the adjacent grazed sampling area was utilized so heavily by grazing animals in 1976-77 that virtually no plant material remained on the soil surface.

Populations of germinable seeds on these two sites on October 1, 1977 (Tables 15a and $b$ ), were low compared to those at the SFRFS (Tables 10a and b). The natural area had 6,300 germinable seeds $/ \mathrm{m}^{2}$ and the grazed area, 5,800 (Tables 15a and b). This was only 24 per cent of the average germinable seed population for the same season at the SFRFS (Tables 10a and b). The ratio of seedlings established 5 weeks after the initial rain to germinable seeds on Oct. 1 was similar at the two sites, with 56 to 67 per cent at the SJER and 60 to 73 percent at the SFRFS. The percentage of residual germinable seeds 5 weeks after the initial rain was also similar, with 5 to 7 percent at the SJER and 1 to 6 per cent at the SFRFS. Bromus mollis was not the overwhelming dominant of the germinable seed reserves at the SJER during this study, accounting for only 6 to 19 per cent of the germinable seeds compared to an average of 42 per cent at the SFRFS. The two species of Erodium, E. botrys and E. cicutarium (L.) L'Her. ex Ait. were large contributors to germinable seed reserves in this drought year (Tables 15a and b). Normally E. cicutarium is a minor component of the plant biomass, occurring on open rolling slopes.

There were no exotic species of Trifolium on the sampling locations at the SJER. The native clover T. microcephalum Pursh and other native legumes, Lupinus bicolor Lindl., Lotus strigosus (Nutt $\times$ T. and G.) Greene, and L. Purshianus (Benth.) Clem. and Clem., apparently filled an ecological niche similar to that occupied by the exotic legumes at the SFRFS. At the SFRFS the native and exotic legumes accounted for 20 to 35 per cent of the germinable seed reserve on October 1, 1977 (Tables 10a and b), and at the SJER, the native legumes accounted for 19 to 32 percent (Tables $15 \mathrm{a}$ and $\mathrm{b}$ ).

The seed crop during 1977-78 increased germinable seeds an average 2.8 times of the previous year's crop. In the grazed area, the annual grass Vulpia megalura increased from 5 to 45 per cent of the germinable seed reserve (Table 16). In the natural area, Bromus diandrus increased from 1 to 13 per cent. There was very poor agreement between the percent species composition of the germinable seed population on October 1, 1977, and the plants that were established March 3, 1978 (Tables 16 and 17). A low of 3 per cent and a high of 26 per cent of the variation in plant frequency on March 3, 1978, was accounted for by variation in the October 1,1977 , germinable seed population, as was 7 to 19 per cent of the 1978 variation in germinable seed reserves. Variation in plant frequency on March 3, 1978, accounted for 3 per cent of the variation in 1978 germinable seeds on grazed areas and 29 per cent of that on ungrazed areas. At the SFRFS, 1977-1978 was the growing season during which we obtained the best correlation between germinable seeds and subsequent established plant population (Table 8b).

\section{General considerations}

The most striking finding of this study was the relatively few germinable seeds that carried over from one growing season to germinate during the next growing period. The lack of residual germinable seeds was especially striking among the dominant annual grasses. There apparently is no adaptative advantage in maintaining a large reserve of 


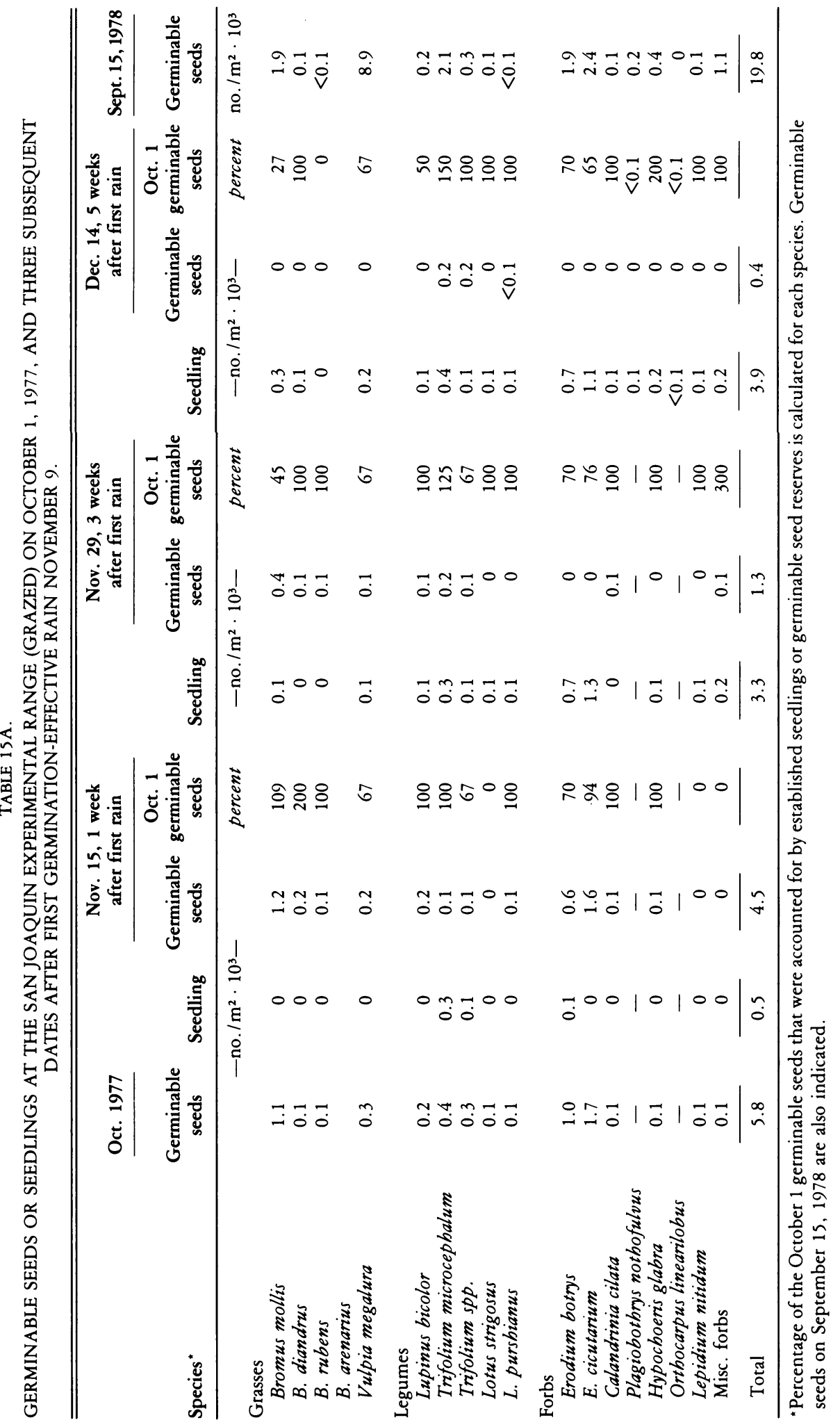




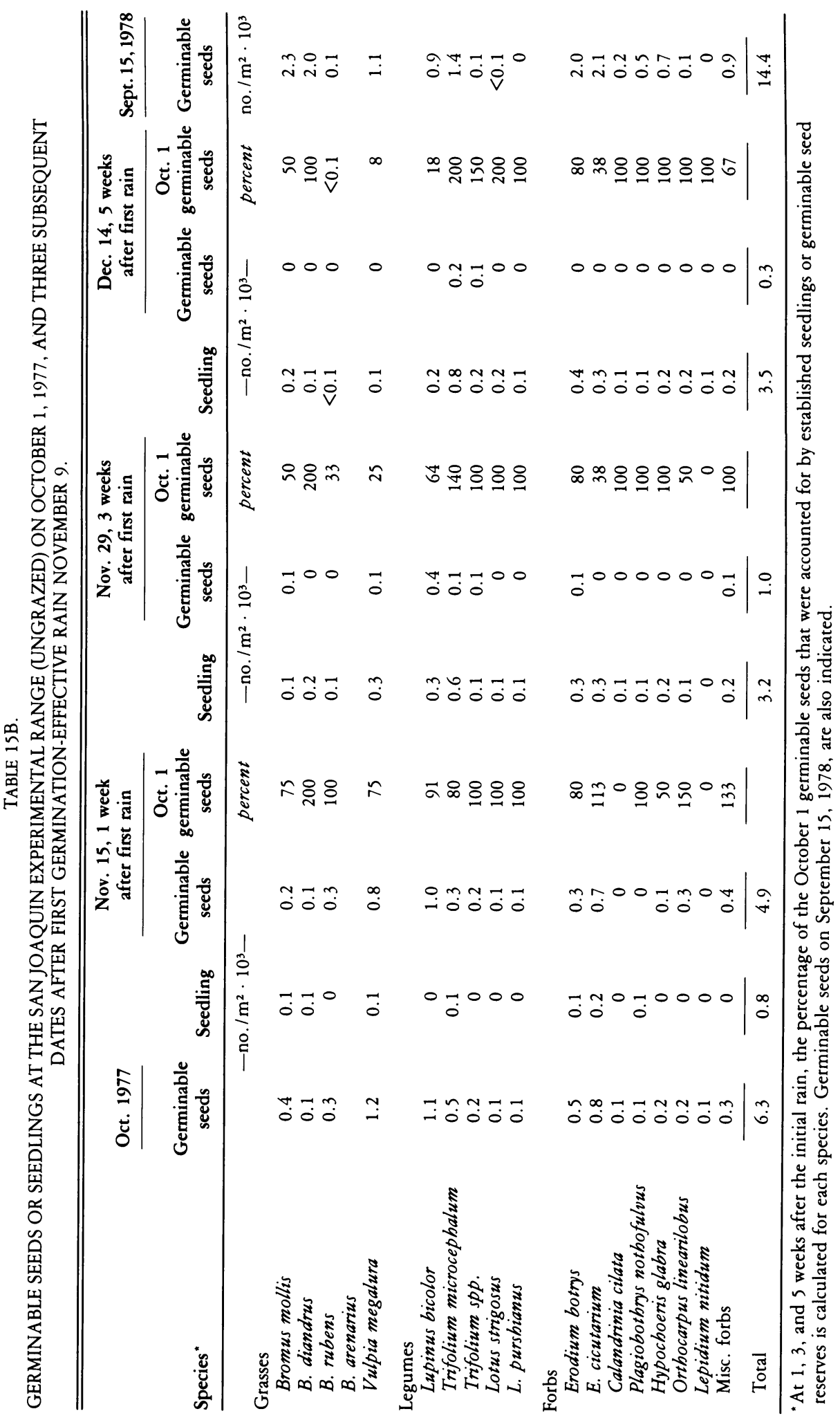


TABLE 16.

SPECIES COMPOSITION OF GERMINABLE SEED RESERVES OCTOBER 1, 1977, AND SEPTEMBER 15, 1978, AND ESTABLISHED PLANTS IN GRAZED AND UNGRAZED AREAS AT THE SAN JOAQUIN EXPERIMENTAL RANGE (1977-78)

\begin{tabular}{|c|c|c|c|c|c|c|}
\hline \multirow[b]{2}{*}{ Species * } & \multicolumn{2}{|c|}{$\begin{array}{l}\text { Germinable seeds } \\
\text { Oct. } 1,1977\end{array}$} & \multicolumn{2}{|c|}{$\begin{array}{c}\text { Plants } \\
\text { Mar. 3, } 1978\end{array}$} & \multicolumn{2}{|c|}{$\begin{array}{l}\text { Germinable seeds } \\
\text { Sept. } 15,1978\end{array}$} \\
\hline & Grazed & Ungrazed & Grazed & Ungrazed & Grazed & Ungrazed \\
\hline & \multicolumn{6}{|c|}{ percent } \\
\hline \multicolumn{7}{|l|}{ Grasses } \\
\hline Bromus mollis & 19 & 6 & 4.7 & 1.6 & 10 & 16 \\
\hline B. diandrus & 2 & 1 & 0.4 & 29.5 & $<1$ & 13 \\
\hline B. rubens & 2 & 5 & 0 & 0.9 & $<1$ & 1 \\
\hline Vulpia megalura & 5 & 19 & 3.1 & 0 & 45 & 8 \\
\hline \multicolumn{7}{|l|}{ Legumes } \\
\hline Lupinus bicolor & 3 & 17 & 4.8 & 1.6 & 1 & 6 \\
\hline Trifolium spp. & 12 & 11 & 23.0 & 26.0 & 13 & 11 \\
\hline Lotus strigosus & 2 & 1 & 2.4 & 0.3 & $<1$ & $<1$ \\
\hline L. purshianus & 2 & 1 & 0.6 & 0.8 & $<1$ & 0 \\
\hline \multicolumn{7}{|l|}{ Forbs } \\
\hline Erodium botrys & 17 & 8 & 31.1 & 15.7 & 10 & 14 \\
\hline E. cicutarium & 28 & 13 & 9.1 & 5.2 & 12 & 15 \\
\hline Calandrinia ciliata & 2 & 2 & 4.8 & 6.7 & $<1$ & 1 \\
\hline Plagiobothrys notbofulvus & 0 & 1 & 1.2 & 1.7 & $<1$ & 3 \\
\hline Hypochoeris glabra & 2 & 4 & 1.0 & 0.3 & 2 & 5 \\
\hline Orthocarpus linearilobus & 0 & 4 & 2.9 & 0.8 & 0 & 1 \\
\hline Lepidium nitidum & 2 & 2 & 0 & 0 & $<1$ & 0 \\
\hline Misc. species & 2 & 5 & 10.9 & 8.9 & 6 & 6 \\
\hline
\end{tabular}

-Species composition of germinable seeds based on density per $6.25 \mathrm{~cm}^{2}$ and that of plants based on frequency (1000 points/community).

TABLE 17

CORRELATION COEFFICIENTS FOR RELATIONSHIPS BETWEEN GERMINABLE SEEDS ON OCTOBER 1, 1977, PLANT FREQUENCY ON MARCH 3, 1978, AND GERMINABLE SEEDS ON SEPTEMBER 15, 1978, ON THE GRAZED AND UNGRAZED AREAS AT THE SAN JOAQUIN EXPERIMENTAL RANGE

\begin{tabular}{lcccc}
\hline \hline & \multicolumn{2}{c}{$\begin{array}{c}\text { Mar. 3, 1978 } \\
\text { plant frequency }\end{array}$} & \multicolumn{2}{c}{$\begin{array}{c}\text { Sep. 15, 1978 } \\
\text { germinable seeds }\end{array}$} \\
\cline { 5 - 6 } Item & Grazed & Ungrazed & Grazed & Ungrazed \\
\hline $\begin{array}{l}\text { Oct. 1, 1977 } \\
\text { germinable seeds }\end{array}$ & 0.51 & 0.17 & 0.27 & 0.44 \\
$\begin{array}{l}\text { Mar. 3, 1978 } \\
\text { plant frequency }\end{array}$ & - & - & 0.16 & 0.54 \\
\hline
\end{tabular}


germinable seeds in the litter and soil. This conclusion implies that the occurrence of a climatic event that nearly completely eliminates the plant population before seed maturity is extremely rare.

A second finding of this study was the rapid depletion of the current year's seed reserves once seedbed conditions were conducive for germination.

Defining seedbed conditions that are conducive to the total commitment of the germinable seed reserves is basic in interpreting the results of this investigation. Such definition is not simple, because the pertinent environmental influences change over time, and, similarly, the inherent physiological responses of plant species also change with the advancing season.

Although it is extremely rare, we had during the early stages of this study an example of partial germination during August (Raguse, Young, and Evans, 1977). Obviously, seedbed temperatures are higher during August, and a given amount of moisture is less effective in inducing germination than it would be later in the fall, with cooler seedbed temperatures. This relationship is complicated by the inherent physiology of species such as Bromus mollis, whose peak germination is reached in 2 weeks in August and 1 week in October.

During the course of the study we had numerous rains during September, some of which induced germination (1976) and some of which, with nearly identical quantities of moisture, did not induce germination (1977).

Germination in September followed by drought during October is a tempering factor modifying the adaptive advantage of simultaneous germination. The tremendous oversupply of germinable seeds in comparison with the maximum density of seedling establishment provides a safety factor against the contingency of October drought. In a year with normal moisture for seed production and germination, only 20 to 30 per cent of the reproductive reserve of the major species becomes established seedlings. The remaining 70 to 80 per cent probably remain for 1 to 2 weeks in reserve against the interruption of the germination-establishment phase by drought. How do these reserve seeds escape germination, especially when they largely disappear from the reproductive reserve within 5 weeks if the germination-establishment phase is not interrupted by drought? Apparently, the number of physical positions within the seedbed that support environments (safesites) conducive to germination are limited, and seeds that are not dispersed to the safesites are physically kept from germination. Seeds in partial safesites begin to germinate and then die as indicated by the large number of dead seeds with radicles emerged found in these seedbeds (Bartolome, 1979). An exception to this generalization is Erodium botrys, in which a large portion of the annual seed production, through the mechanism of seed burial, is placed in safesites for germination. All germination strategies involve tradeoffs, and the assured safesite germination of $E$. botrys can lead to wholesale losses with postgermination drought. The relationship of seedling establishment and germination safesites is further borne out by the increase in the ratio of germinable seeds to established seedlings in 1977, when a higher percentage of the seed reserves reduced by drought became seedlings with the return of adequate moisture."

The majority of the germinable seeds that carry over from year to year are seeds of legumes, and specifically, in the SFRFS communities, those of the exotics Trifolium birtum and T. subterraneum. These two species accounted for so much of the seed reserve at the SFRFS that we wondered what would have happened to the community during the drought if it were not for these legumes. At the SJER we found exactly the same situation with nonexotic legumes. Species of native legumes filled the same portion of the plant community at the SJER as the exotics did at SFRFS. 
In the introduction to this paper we cited the work of Heady and his students in relating the composition of California grassland communities to the amount of litter that is left on the soil surface (Bartolome, 1976; Heady, 1956, 1958). If sufficient litter is left on the soil surface after grazing, dominance by desirable annual grasses the next season is probably assured. The amount of litter that is left on the soil surface influences both the number of grass seeds available to germinate and the quality of the seedbed in supporting germination. Litter and microtopography combine to enhance the potential of the seedbed for supporting germination (Evans and Young, 1970, 1972). If a seedbed is largely bare because of excessive grazing or drought, the species with self-burial mechanisms will be favored over the grass species that require litter coverage for germination. The quality of the seedbed seems likely to control the species composition of annual rangeland communities. So-called "clover years" or "filaree years" are reflections of seedbed quality.

The most striking response of these plant communities to the 2 years of severe drought was their endurance. Densities of seeds and seedlings were dramatically reduced, but proportions in the species composition remained relatively stable both during and after the drought.

\section{Synthesis}

Based on the results of this study we suggest a model of the dynamics of the seasonal seed reserve (Fig. 8). Although there have been many and conflicting estimates of seed production in these communities, and although estimating seed production was not a goal of this study, we did obtain a measure of the total reproductive potential during the summer; this indirectly estimates annual seed production.

The flow-diagram model (Fig. 8) portrays the fate of an average of 200,000 germinable seeds $/ \mathrm{m}^{2}$ on October 1 before the germination-initiating rain. Earlier in the summer, as indicated, part of the annual germinable seed reserve is dormant or at least delayed in germination. The gradual increase in germinability during the summer makes it impossible to estimate, by our inference techniques, how many seeds are lost through predation. The loss of germinable seeds after the initial flush of germination was obtained from direct sampling. However, we have no measurement of how this significant portion of the annual seed reserve (about $75 \%$ ) was lost.

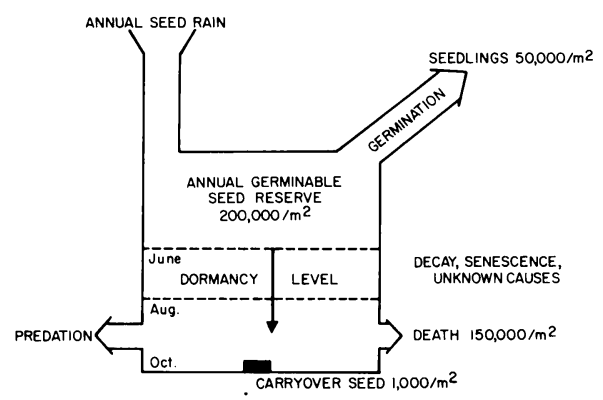

Fig. 8. Diagrammatic flow chart for the proposed model of the dynamics of the annual germinable seed reserve. 


\section{LITERATURE CITED}

ALLARD, R. W.

1965. Genetic systems associated with colonizing ability in predominately self-pollinated species. In: The genetics of colonizing species. H. G. Baker and G. L. Stebbins (Eds.) New York: Academic Press. pp. 49-76.

BARTOLOME, J. W.

1976. Germination and establishment of plants in California annual grassland. Ph.D. dissertation. Univ. of Calif. Berkeley. 187 pp.

1979. Germination and seedling establishment in California annual grassland. J. Ecol. 67:273-81

BATZII, G. O., and G. A. PITELKA

1970. Influence of meadow mouse populations on California grasslands. Ecology. 51:1027-39.

BISWELL, H. H., and C. A. GRAHAM

1956. Plant counts and seed production on California annual-type ranges. J. Range Manage. 9:116-18.

BRENCHLEY, W. E.

1918. Buried weed seeds. J. Agric. Sci. 9:1-31.

BRENCHLEY, W. E., and K. WARINGTON

1930. The weed seed population of arable soil. I. Numerical estimation of viable seeds and observations

BURCHAM, L. T. on their natural dormancy. J. Ecol. 18:235-72.

1956. California Rangeland. Calif. Division Forestry, Sacramento. 261 pp.

BUTTERY, R. F., and L. R. GREEN

1958. A checklist of plants of the San Joaquin Experimental Range. U.S. Forest Serv., Calif. Forest and Range Exp. Sta., Misc. Paper 23. 32 pp. Berkeley, CA.

CHANG, K. K.

1965. Detailed soil survey of the San Joaquin Experimental Range. O'Neal's California. USDA Soil Conservation Service and Pac. Southwest Forest and Range Exp. Sta. Forest Service. 26 pp.

DRAPER, N. R., and H. SMITH

1966. Applied regression analysis. New York: John Wiley \& Sons, Inc., 407 pp.

DUNCAN, D. A., and R. G. WOODMANSEE

1975. Forecasting forage yield from precipitation in California's annual rangeland. J. Range Manage. 28:327-29.

EVANS, R. A., B. L. KAY, and J. A. YOUNG

1975. The microenvironment of a dynamic annual community in relation to range improvement. Hilgardia 43:79-102.

EVANS, R. A., and R. M. LOVE

1957. The step-point method of sampling-A practical tool in range research. J. Range Manage. 10: 208-12.

EVANS, R. A. and J. A. YOUNG

1970. Plant litter and establishment of alien annual species in rangeland communities. Weed Sci. 18:697-703.

1972. Microsite requirements for establishment of annual rangeland weeds. Weed Sci. 20:350-356.

1975. Enhancing germination of dormant caryopses of downy brome. Weed Sci. 23:354-357.

1980. Influence of abiotic factors in annual grasslands of California. Abstracts, Soc. for Range Management 33rd Annual Meeting. p 12.

EVANS, R. A., J. A. YOUNG, and B. L. KAY

1973. Germination of winter annual species from a rangeland community treated with paraquat. Weed Sci. 22:85-187.

HARPER, J. L.

1977. Population biology of plants. New York: Academic Press. 892 pp.

HEADY, H. F.

1956. Changes in a California annual plant community induced by manipulation of natural mulch. Ecology 37:798-812.

1958. Vegetational changes in the California annual type. Ecology 39:402-416.

HEADY, H. F.

1977. Valley grassland. In: Terrestrial vegetation of California. M. G. Barbour and J. Major (Eds.) New York: John Wiley \& Sons. 1002 pp.

HEADY, H. F. and D. T. TORRELL

1959. Forage preferences exhibited by sheep with esophageal fistulas. J. Range Manage. 12:28-34.

HEDRICK, D. W.

1948. The mulch layer of California annual ranges. J. Range Manage. 1:22-25.

JAMES, E. B.

1969. Botanical composition and productivity in the California annual grassland in relation to rainfall. M.S. Thesis, Univ. Calif., Berkeley. 47 pp. 
MAJOR, J., C. M. MCKELL, and L. J. BERRY

1960. Improvement of medusahead infested rangelands. Univ. Calif. Agric. Exp. Sta. Leafl. 123. 3 pp. MAJOR, J., and W. T. PYOTT

1966. Buried, viable seeds in two California bunchgrass sites and their bearing on the definition of a flora. Vegetation 13:253-82.

MURPHY, A. H.

1970. Predicting forage yield based on fall precipitation in California annual grasslands. J. Range Manage. 23:363-65.

RAGUSE, C. A., J. A. YOUNG, and R. A. EVANS

1977. Germination of California range plants in response to a summer rain. Agron. J. 69:327-29.

STEBBINS, G. L., JR.

1957. Self-fertilization and population variability in the higher plants. Am. Naturalist 91:337-54.

SUMNER, D. C., and R. M. LOVE

1961. Resident range cover often cause of seeding failure. Calif. Agric. 15 (2):6.

WILLIAMS, W. A., R. M. LOVE, and L. J. BERRY

1957. Production of range clovers. Univ. Calif. Agric. Exp. Sta. Circ. 458. 19 pp.

YOUNG, J. A., and R. A. EVANS

1975. Germinability of seed reserves in a big sagebrush community. Weed Sci. 23:358-64.

YOUNG, J. A., R. A. EVANS, and B. L. KAY

1973. Temperature requirements for seed germination in an annual-type range community. Agron. J. 65:656-59.

1975. Dispersal and germination dynamics of broadleaf filaree, Erodium botrys (Cav.) Bertol. Agron. J. 67:54-57.

YOUNG, J. A., R. A. EVANS, and R. E. ECKERT, JR.

1968. Germination of medusahead in response to temperature and afterripening. Weed Sci. 16:92-95. 
